\title{
The SUi Generis Nature of Aboriginal Rights: Does it MAKe A Difference?
}

\author{
JOHN BORROWS` AND LEONARD I. ROTMAN *
}

The authors trace the development of the use of the term sui generis to describe Aboriginal legal rights, noting that this is not in fact a recent phenomenon. They explain the doctrine as a balance between common law and Aboriginal conceptions, acting as an aid to the development of the common law in a manner which accommodates cultural differences and unique Aboriginal legal rights. The authors critically analyze recent judicial employment of the doctrine, and offer suggestions as to how it could best be employed to reconcile unique Aboriginal issues with the framework of the common law.
Les auteurs montrent comment la locution sui generis a été utilisée pour décrire les droits autochtones en common law, et notent que le phénomène n'est en fait pas récent. Selon eux, la doctrine réalise un équilibre entre la common law et les conceptions autochtones, et permet d'elaborer la common law en tenant compte des differences culturelles et des droits ancestraux uniques des peuples autochtones. Les auteurs font une anabyse critique de l'emploi récent du droit sui generis par les tribunaux et suggèrent comment il pourrait le mieux servir à concilier les questions autochtones et le cadre de la common law.

\section{TABLE OF CONTENTS}

I. INTRODUCTION $\ldots \ldots \ldots \ldots \ldots \ldots \ldots \ldots \ldots \ldots \ldots$

A. THE EXISTING ABORIGINAL AND TREATY

RIGHTS OF THE ABORIGINAL PEOPLES OF

CANADA...: HISTORIC ROOTS OF THE

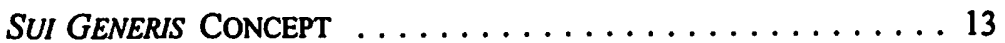

B. ...ARE HEREBY RECOGNIZED...: TRANSITIONS

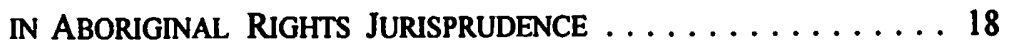

C. ...AND AFFIRMED: CONTEMPORARY APPLICATION

OF THE SUI GENERIS CONCEPTION

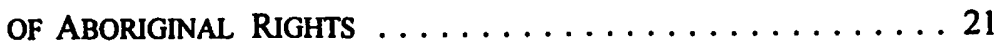

II. THE Paradox, PURPOSE AND CONTENT

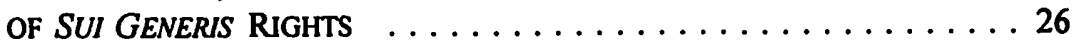

A. THE SUI GENERIS PRINCIPLE: THE

External Challenge ................. 26

B. SUI GENERIS ABORIGINAL RIGHTS WITHIN

THE COMMON LAW: THE INTERNAL CHALlENGE $\ldots \ldots \ldots 32$

III. Meeting the SuI Generis "Challenge" $\ldots \ldots \ldots \ldots \ldots \ldots \ldots 37$

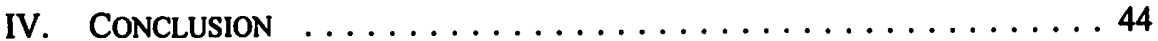

B.A., M.A., LL.B., LL.M., D.Jur., Associate Professor, Faculty of Law, University of British Columbia.

- $\quad$ B.A., LL.B., LL.M., S.J.D. Candidate, of the Ontario Bar, Assistant Professor, Faculty of Law, University of Alberta. 
...I am satisfied that a jurisprudential analysis of the concepts underlying "rights" in common law or westem legal thought is of little or no help in understanding the rights now held by aboriginal peoples and now recognized and affirmed by the common law and by the Constitution.... In short, it is not only aboriginal title to land that is sui generis, all aboriginal rights are sui generis.

Lambert J.A. in Delgamuukw v. British Columbia (1993), 104 D.L.R. (4th) 470 at 643-44 (B.C.C.A.). ${ }^{1}$

\section{INTRODUCTION}

The term sui generis connotes uniqueness and difference; literally translated, it means "of its own kind or class." Aboriginal rights were first labelled as sui generis by the Supreme Court of Canada in Guerin v. $R^{3}$ Since Guerin, judicial decision-making has extended the sui generis appellation from more conventional subjects, such as hunting, fishing, and land rights, to issues like Indian treaties and the relationship between the Crown and First Nations. ${ }^{4}$ However, the judiciary has yet to extol the virtues of this phrase in these various contexts. Meanwhile, the use of the sui generis characterization is still growing. Lambert J.A.'s statement in Delgamuukw is a logical progression of the previous judicial trend of describing only specific Aboriginal rights ${ }^{5}$ as sui generis. If Canadian Aboriginal rights law continues to proceed under the assumption that all Aboriginal rights are sui generis, the courts will be faced with a myriad of questions. For instance, what does the term sui generis mean in the Aboriginal rights context? What are the implications of describing Aboriginal rights as sui generis? When or how is the judiciary to impose sui generis standards for Aboriginal rights? Moreover, does the fact that Aboriginal rights are to be viewed as unique or different from other rights add anything to their understanding?

In describing all Aboriginal rights as sui generis, Lambert J.A. continued a trend imbricated in the very foundation of Aboriginal rights jurisprudence. ${ }^{6}$ Aboriginal rights have always been regarded as different from other common law rights. ${ }^{7}$ They do not

For a critique of the British Columbia Court of Appeal's reasons in Delgamuukw, see A. Bowker, "Sparrow's Promise: Aboriginal Rights in the B.C. Court of Appeal" (1995) 53 U.T. Fac. L. Rev. 1.

See Black's Law Dictionary, 6th ed. (St. Paul, Minn.: West, 1990) at 1434. (1984), 13 D.L.R. (4th) 321 (S.C.C.) [hereinafter Guerin].

Among the more notable decisions are Simon v. R. (1985), (1986) 24 D.L.R. (4th) 390 (S.C.C.) [hereinafter Simon]; R. v. Sioui (1990), 70 D.L.R. (4th) 427 (S.C.C.) [hereinafter Sioui]; $R$ v. Sparrow (1990), 70 D.L.R. (4th) 385 (S.C.C.) [hereinafter Sparrow]; and Delgamuukw v. British Columbia (1993), 104 D.L.R. (4th) 470 (B.C.C.A.) [hereinafter Delgamuukw (C.A.)], vary'g (1991), 79 D.L.R. (4th) 185 (B.C.S.C.) [hereinafter Delgamuukw (S.C.)].

Where not otherwise specified, the use of the term "Aboriginal rights" in this article refers to the collection of rights belonging to the Aboriginal peoples of Canada, such as, but not restricted to, land rights, hunting and fishing rights, and self-govemment.

See Calder v. British Columbia (A.G.) (1973), 34 D.L.R. (3d) 145 at 152-53, 156 (per Judson J.) and at 200 (per Hall J.) (S.C.C.); Guerin, supra note 3 at 335.

The use of the phrase "other common law rights" recognizes the fact that Aboriginal rights, while maintaining their own, independent existence, are a part of Canadian common law. See Roberts v. Canada (1989), 57 D.L.R. (4th) 197 (S.C.C.) [hereinafter Roberts]. 
take their source or meaning from the philosophies that underlie the western canon of law. ${ }^{8}$ Although equal in importance and significance to other rights, ${ }^{9}$ Aboriginal rights are viewed differently because they are held only by Aboriginal members of Canadian society. ${ }^{10}$ This approach to interpreting Aboriginal rights is appropriate because, in many respects, Aboriginal peoples are unique within the wider Canadian population. Before their characterization as sui generis, previous common law doctrines often penalized Aboriginal difference." Now, the sui generis appellation potentially turns negative characterizations of Aboriginal difference into positive points of protection. Its very existence recognizes that Aboriginal rights stem from alternative sources of law, ${ }^{12}$ that reflect the unique historical presence of Aboriginal peoples in North America. ${ }^{13}$

While the sui generis doctrine of Aboriginal rights places significant emphasis upon Aboriginal difference, it does not ignore the similarities between Aboriginal and non-Aboriginal peoples. A legal doctrine which focused exclusively upon the differences between Aboriginal and non-Aboriginal people would distort the reality of Crown-Aboriginal relations. Aboriginal and non-Aboriginal people have developed numerous ways of relating to one another, which over the centuries have produced some similarities between the various groups. ${ }^{14}$ Both Aboriginal and non-Aboriginal people often share interests in the same territories, ecosystems, economies, ideologies and institutions. ${ }^{15}$ While imperfect, and often skewed to the disadvantage of the Aboriginal people, these points of connection cannot be ignored. The sui generis doctrine expresses the confidence that there are enough similarities between the groups to enable them to live with their differences. Under this doctrine, points of mutually shared agreement can be highlighted and issues of difference can be preserved to facilitate more productive and peaceful relations. The sui generis doctrine reformulates similarity and difference and thereby captures the complex, overlapping, and exclusive identities and relationships of the parties.

In expressing this interactive relationship, the Supreme Court has emphasized that the essence of Aboriginal rights is their bridging of Aboriginal and non-Aboriginal cultures. ${ }^{16}$ As such they are "neither English nor Aboriginal in origin," they are "a

R. v. Van der Peet, [1996] 4 C.N.L.R. 177 at 190 (para. 19) (S.C.C.) [hereinafter Van der Peet (S.C.C.)].

- Delgamuukw (C.A.), supra note 4 at 649 , per Lambert J.A. See also the consolidated cases of Western Australia v. Commonwealth; Wororra Peoples v. State of Western Australia; Biljabu v. State of Western Australia (1995) 128 A.L.R. I (H.C. Aust.).

10 Delgamuukw, ibid.

" See P. Macklem, "First Nations Self-Government and the Borders of the Canadian Legal Imagination" (1991) 36 McGill L.J. 382. Van der Peet (S.C.C.), supra note 8 at 198 (para. 40) (Aboriginal rights are based in the traditional laws and customs of the pre-existing societies of Aboriginal peoples). Ibid. at 193-94; see also B. Slattery, "The Organic Constitution: Aboriginal Peoples and the Evolution of Canada" (1996) 34 Osgoode Hall L. J. 101.

i4 See J. Webber, "Relations of Force and Relations of Justice: The Emergence of Normative Community Between Colonists and Aboriginal Peoples" (1995) 33 Osgoode Hall L.J. 623.

is See J. Borrows, "Living Between Water and Rocks: First Nations, Environmental Planning and Democracy" (1997) 47 U.T.L.J. (forthcoming). 
form of intersocietal law that evolved from long-standing practices linking the various communities."17 The recognition of Aboriginal law and legal perspectives in the face of Crown assertions of sovereignty is at the heart of why courts must describe Aboriginal rights as sui generis. ${ }^{18}$ Courts must not interpret Aboriginal rights using conventional common law doctrines alone ${ }^{19}$ because of the continued existence of prior Aboriginal legal regimes. ${ }^{20}$ The selective application of conventional common law categories devalues Aboriginal similarities and differences and makes Aboriginal-derived law seem incompatible, or inferior, ${ }^{21}$ to other sources. ${ }^{22}$ To avoid these challenges, the courts can, and should, approach the interpretation of Aboriginal rights as a search for consistency between these various spheres of law. ${ }^{23}$ Other factors, such as Aboriginal conceptions of the meaning of those rights, can be

Ibid. quoting from B. Slattery, "The Legal Basis of Aboriginal Title" in F. Cassidy, ed., Aboriginal Title in British Columbia: Delgamuukw v. The Queen, (Lantzville: Oolichan Books, 1992) 113 at 120-21.

For one community's continued use of traditions, customs, and systems of government, in the face of Crown assertions of sovereignty, see J.J. Borrows, "A Genealogy of Law: Inherent Sovereignty and First Nations Self-Government" (1992) 30 Osgoode Hall L.J. 291 [hereinafter "A Genealogy of Law"].

This is why, as Judson J. observed in Calder, supra note 6 at 156, the characterization of Aboriginal title as a personal and usufructuary right was not helpful in the determining the nature of Indian title. See also Guerin, supra note 3 at 339.

As McLachlin J. observed in Van der Peet (S.C.C.), supra note 8 at 257 (para. 230), "a prior legal regime give[s] rise to Aboriginal rights."

Two of the most important cases in Canadian Aboriginal rights jurisprudence have stated that Crown law and interests were paramount to those of the Aboriginal peoples. In St. Catherine's Milling and Lumber Co. v. The Queen (1888), 14 App. Cas. 46 at 54 (P.C.) [hereinafter St. Catherine's], the Privy Council stated that "there has been all along vested in the Crown a substantial and paramount estate, underlying the Indian title." In Sparrow, supra note 4 at 404, a similar finding was put forth (despite other intimations to the contrary): "[T]here was from the outset never any doubt that sovereignty and legislative power, and indeed the underlying title, to such lands vested in the Crown."

For further critique of these conclusions, see M. Asch \& P. Macklem, "Aboriginal Rights and Canadian Sovereignty: An Essay on R. v. Sparrow" (1991) 29 Alta. L. Rev. 498; L.I. Rotman, Parallel Paths: Fiduciary Doctrine and the Crown-Native Relationship in Canada (Toronto: University of Toronto Press, 1996) c. 3 [hereinafter Parallel Paths].

In addition, recent case law from British Columbia has held that in the case of conflict between Aboriginal laws and Canadian laws, the latter will prevail: "After [the colony of British Columbia was formed in 1858] Aboriginal customs, to the extent they could be described as laws before the creation of the colony ... ceased to have any force, as laws, within the colony." See Delgamuukw (S.C.), supra note 4 at 453, accepted in R. v. Williams, [1995] 2 C.N.L.R. 229 (B.C.C.A.).

The contested origins of legal principles in Aboriginal rights jurisprudence are described in $\mathrm{K}$. McNeil, Common Law Aboriginal Title (Oxford: Clarendon Press, 1989); and B. Clark, Native Liberty, Crown Sovereignty: The Existing Aboriginal Right of Self-Government in Canada (Montreal: McGill-Queen's University Press, 1990).

See J. Webber, "The Jurisprudence of Regret: The Search for Standards of Justice in Mabo" (1995)

17 Sydney L. Rev. 5, at 27-28:

Judges have, by the nature of their office, a particular concem with the normative structure of a community through time. The very means by which they justify their decisions require that they reflect upon the substance of previous judgements, that they care about consistency over time and across contemporaneous judgements, and that they ... take seriously the law's claim to be a framework of justice. 
considered in the judicial formulation of Aboriginal rights, ${ }^{24}$ and can be given equal weight with the perspective of the common law. ${ }^{25} \mathrm{~A}$ furtherance of these same sui generis principles results in a conceptualization of Aboriginal rights that harmonizes Aboriginal and non-Aboriginal laws

This article examines the development, use and impact of the term sui generis to describe Aboriginal rights. It offers suggestions as to why Aboriginal rights have been characterized as sui generis and describes the basis for the need to use expansive, sui generis principles. In addition, it comments on some of the positive and negative aspects of the description of Aboriginal rights as sui generis. As such, it explores the challenge courts face in reconciling notions of Aboriginal uniqueness within the framework of the common law. In so doing, it seeks to provide a greater understanding for the judicial cloaking of Aboriginal rights behind their sui generis sheath as well as the implications of this activity for the Crown ${ }^{26}$ and Aboriginal peoples in Canada.

\section{A. The Existing Aboriginal and Treaty Rights \\ of the Aboriginal Peoples of Canada...: HISTORIC ROOTS OF THE SUI GENERIS CONCEPT}

The judiciary's understanding that Aboriginal rights do not necessarily correspond to other common law rights is not an entirely recent phenomenon. In fact, judicial recognition of the unique nature of Aboriginal rights may be traced back to the earliest origins of North American Aboriginal rights jurisprudence. ${ }^{27}$ This recognition was pivotal, for example, in one of the United States Supreme Court's first decisions on Aboriginal rights, Johnson and Graham's Lessee v. M'Intosh.$^{28}$ The case centred around a dispute over the ownership of former Indian land situated within the boundaries of

The Supreme Court of Canada has held that "it is possible, and, indeed, crucial, to be sensitive to the Aboriginal perspective itself on the meaning of the rights at stake" (Sparrow, supra note 4 at 411).

Taking the perspective of Aboriginal peoples themselves allows for the incorporation of Aboriginal perspectives and principles as part of the law's formulation. The inclusion of Aboriginal legal principles is possible because the sui generis concept "overarches and embraces" Aboriginal and British legal systems: see B. Slattery, "Understanding Aboriginal Rights" (1987) 66 Can. Bar Rev. 727 at 745. This is an important clarification of Canadian law dealing with Aboriginal peoples and issues. Sensitivity to Aboriginal perspectives suggests that domestic Canadian law may be of increasing value for Aboriginal peoples in clarifying their rights because it can take account of legal concepts that are not derived from Western categories of law. Legal interpretation under this precept stems from a perspective that is more consistent with Aboriginal understandings of their rights.

Van der Peet (S.C.C.), supra note 8 at 202 (para. 49).

For the purposes of this article, the use of the term "the Crown" refers to the sovereign power and position of the goveming bodies in Canada as a collective whole. Where specific emanations of the Crown are referred to, those distinctions will be clearly made in the text.

Mohegan Indians v. Connecticut (1705-1773) in J.H. Smith, Appeals to the Privy Council from the American Plantations (New York: Columbia University Press, 1950); for context and commentary on this case see M. Walters, "Mohegan Indians v. Connecticut (1705-1773) and the Legal Status of Customary Laws and Government in British North America" (1995) 33 Osgoode Hall L. J. 785. 
the original Virginia colony. Johnson was the successor-in-title of a colonist who had purchased the land from its original Indian owners. M'Intosh had purchased his title from the United States government, which had obtained it from Virginia after the American Revolution. Although the court ruled in favour of M'Intosh, Marshall C.J. held that while Johnson's title was valid in accordance with Indian law, its different source rendered it neither valid nor enforceable in the American courts:

If an individual might extinguish the Indian title for his own benefit, or, in other words, might purchase it, still he could acquire only that title. Admitting their power to change their laws or usages ... still it is a part of their territory, and is held under them, by a title dependent on their laws. The grant derives its efficacy from their will; and ... the courts of the United States cannot interpose for the protection of the title. The person who purchases lands from the Indians, within their territory, incorporates himself with them, so far as respects the property purchased; holds their title under their protection, and subject to their laws.... [T]he plaintiffs do not exhibit a title which can be sustained in the Courts of the United States. ${ }^{29}$

In observing that non-native people could hold title to land under Indian law, the court recognized the continued existence of indigenous law, even in the face of Crown assertions of sovereignty. ${ }^{30}$

Almost one hundred years after Johnson v. M'Intosh, the Judicial Committee of the Privy Council was faced squarely with the question of the relationship of indigenous law to the common law, in the context of land rights. In Re Southern Rhodesia ${ }^{31}$ Lord Sumner considered the meaning of the tribes' claim to ownership, under common law and indigenous legal regimes. He decided that Aboriginal rights to land could only constitute ownership if they ascribed to the characteristics of private property under the common law. Lord Sumner departed from Marshall C.J.'s recognition of the distinct nature of Indian title and determined:

\footnotetext{
It seems to be common ground that the ownership of the lands was "tribal" or "communal," but what precisely that means remains to be ascertained. In any case it was necessary that the argument should go the length of showing that the rights, whatever they exactly were, belonged to the category of rights of private property. ${ }^{32}$
}

The above statement clearly exudes the bias of a colonialist regime. The notion that land ownership exists only where it adheres to common law concepts implies their acceptance at the expense of indigenous principles of ownership. While indigenous laws . are not completely rejected under this formulation, only those forms of ownership which share sufficient similarity with the common law are deemed capable of securing common law protection. Lord Sumner's failure to adequately affirm Aboriginal legal perspectives is amplified in his often-quoted commentary on the differences between Aboriginal legal conceptions and those originating under the common law:

Ibid. at 593, 604-605.

See also Worcester v. State of Georgia, 31 U.S. (6 Pet.) 515 (1832) [hereinafter Worcester].

[1919] A.C. 211 (P.C.).

Ibid. at 233. 
The estimation of the rights of Aboriginal tribes is always inherently difficult. Some tribes are so low in the scale of social organization that their usages and conceptions of rights and duties are not to be reconciled with the institutions or the legal ideas of civilized society. Such a gulf cannot be bridged. It would be idle to impute to such people some shadow of the rights known to our law and then to transmute it into the substance of transferable rights of property as we know them.... On the other hand, there are indigenous peoples whose legal conceptions, though differently developed, are hardly less precise than our own. When once they have been studied and understood they are no less enforceable than rights arising under English law. Between the two there is a wide tract of much ethnological interest....

In this statement Lord Sumner suggests that Aboriginal peoples' "organization" and "civilization" is to be interpreted exclusively by reference to common law notions. However, he simultaneously submits that some indigenous peoples' rights, despite their different origins, are no less developed or enforceable than common law-originated rights. Lord Sumner's initial statement that Aboriginal rights may exist only where they correspond to common law-based rights is somewhat clouded by his latter statement that indigenous legal systems, though different, have their own precision and enforceability. It is unclear from his statement whether Aboriginal rights must adhere to common law-esque notions in order to be enforceable.

The Privy Council's recognition that the common law could affirm and give effect to rights held under indigenous law was made explicit two years later in Amodu Tijani v. Secretary, Southern Nigeria. ${ }^{34}$ Tijani, an Idejo White Cap Chief of the colony of Lagos, claimed compensation for the government's expropriation of land under a Public Lands Ordinance. The Privy Council found that Tijani was entitled to compensation for having transferred full ownership of the land, ${ }^{35}$ along with his title to receive rent or tribute, to the Governor of Lagos. In delivering judgment on behalf of the Privy Council, Viscount Haldane recognized that Aboriginal land rights were both unique and theoretically dissimilar to notions of land ownership existing under the common law. His observations about the nature of indigenous land tenure in many parts of the British Empire led him to warn of the dangers associated with construing Aboriginal title according to common law notions:

Their Lordships make the preliminary observation that in interpreting the native title to land, not only in Southem Nigeria, but other parts of the British Empire, much caution is essential. There is a tendency, operating at times unconsciously, to render that title conceptually in terms which are appropriate only to systems which have grown up under English law. But this tendency has to be held in check closely. ${ }^{36}$

Ibid. at 233-34.

34 [1921] 2 A.C. 399 (P.C.). Interestingly, despite the small time gap between Re Southern Rhodesia, supra note 31 and Amodu Tijani, only Lord Atkinson took part in both decisions.

3s Under what was described as a "communal usufructuary occupation, which may be so complete as to reduce any radical right in the Sovereign to one which only extends to comparatively limited rights of administrative interference" (ibid. at 409-10). 
Viscount Haldane held that the proper method of ascertaining the rights possessed by indigenous people necessitated a study of the particular community's customs and laws. Under this test, Aboriginal title is best understood through considering indigenous history and patterns of land usage, rather than importing the preconceived notions of property rights under the common law. ${ }^{37}$

In Canada, the recognition of indigenous legal values as a valid source for Aboriginal rights came much later. One notable exception was the case of Connolly v. Woolrich, ${ }^{38}$ where Aboriginal customary laws of marriage were found to be valid under the common law. ${ }^{39}$ William Connolly, a fur trader, had married Suzanne, a Cree woman, though the marriage was never solemnized by a religious leader. ${ }^{40}$ After almost thirty years of marriage and six children he treated his marriage to Suzanne as invalid and married his wealthy second cousin, Julia Woolrich. Later, upon William's death, he bequeathed all of his property to Julia and their two children. Following Suzanne's death, her eldest son John sued Julia Woolrich for a share of his father William's estate. He claimed that Suzanne and William's marriage was valid under Cree law and that the couple had communal ownership of the property of the marriage, thereby entitling each to half of their marriage property. At trial, Monk J. held that Suzanne and William's marriage was valid, thereby entitling John to a share of William's estate. He held that while European traders residing in the North West brought their own laws with them as their birthright, those laws did not automatically abrogate existing Aboriginal laws when the groups began to trade with each other. ${ }^{41}$

Connolly v. Woolrich recognized that existing Aboriginal laws were valid regardless of whether they conformed with traditional common law principles. Monk J.'s decision ensured the continuity of indigenous law in the wake of a new legal and political order.

Ibid. at 404: "Abstract principles fashioned a priori are of but little assistance, and are as often as not misleading." (1867), 1 C.N.L.C. 70 (Que. Sup. Ct.) [hereinafter Connolly]. Other nineteenth century cases on the issue of Aboriginal customary laws include $R \mathbf{v}$. Nan-e-quis-a-ka (1889), 1 Territories Law Reports 211 (N.W.T.S.C.) and R. v. Bear's Shin Bone (1899), 3 C.C.C. 329 (N.W.T.S.C.).

That the marriage was never solemnified was a common practice among such marriages during the early nineteenth century: see Royal Commission on Aboriginal Peoples, Partners in Confederation: Aboriginal Peoples, Self-Government, and the Constitution (Ottawa: Minister of Supply and Services Canada, 1993) at 5 (hereinafter "Partners in Confederation"); see also S. Van Kirk, Man Tender Ties: Women in Fur-Trade Society, 1670-1870 (Winnipeg: Watson \& Dwyer, 1980).

"Connolly, supra note 38 at 78-79. Indeed, Monk J. quoted, ibid. at 81, from Marshall C.J. of the U.S. Supreme Court in Worcester, supra note 30, that the British Crown's assertion of suzerainty over North America did not interfere with First Nations' internal affairs and self-government:

Certain it is, that our history furnishes no example, from the first settlement of our country, of any attempt on the part of the crown to interfere with the internal affairs of the Indians, farther than to keep out the agents of foreign powers, who, as traders or otherwise, might seduce them into foreign alliances. The king ... purchased their alliance and dependence by subsidies; but never intruded into the interior of their affairs, or interfered with their self-government, so far as respected themselves only. [emphasis is Monk J.'s] 
However, Canadian courts eventually departed from this vision of Aboriginal rights. ${ }^{42}$ For close to one hundred years the majority of judicial decisions concerning Aboriginal rights primarily involved the competing legislative and commercial interests of the federal and provincial governments, rather than the laws and interests of Native peoples. ${ }^{43}$ The preponderance of these decisions held that Aboriginal rights were premised entirely upon the benevolence of the Crown. They concealed indigenous laws and privileged European claims over Aboriginal lands. Aboriginal land rights soon became characterized exclusively by their description in St. Catherine's Milling and Lumber Co. v. The Queen, ${ }^{44}$ where the Privy Council held that they were "personal and usufructuary" in nature and "dependent upon the good will of the Sovereign."45 Perhaps not coincidentally, the courts which conceptualized this vision of Aboriginal rights did not consider the continued existence of indigenous law, and thus lost the benefit of Aboriginal representation of their interests. ${ }^{46}$

First Nations' treaty rights were also not viewed by Canadian courts as bridging indigenous laws and the common law tradition. Indeed, the Crown's obligations under such treaties were considered to be entirely political rather than legal. They were seen as existing only at the sufferance of the Crown, and were often trivialized to the point of extinction. ${ }^{47}$ Even where the Crown's treaty obligations were viewed as binding, they

Interestingly, American courts also departed from the notion that Aboriginal rights, though differently conceived and originated, were no less enforceable than other common law rights in the latter half of the nineteenth century. See Lone Wolf v. Hitchcock, 187 U.S. 553 (1903). See, for example, St. Catherine 's, supra note 21, aff'g (1887), 13 S.C.R. 577, (1886), 13 O.A.R. 148 (C.A.), (1885), 10 O.R. 196 (Ch. Div.); Ontario v. Canada and Quebec: In re Indian Claims (the Robinson Treaties Annuities Case) (1896), [1897] A.C. 199 (P.C.), aff'g (1895), [1896] 25 S.C.R. 434 [hereinafter Robinson Treaties]; Ontario Mining Company Ltd. v. Seybold (1902), [1903] A.C. 73 (P.C.), aff'g (1901), 32 S.C.R. 1, (1900), 32 O.R. 301 (Div. Ct.), (1899), 31 O.R. 386 (Ch. Div.); and Dominion of Canada v. Province of Canada (the Treaty \#3 Annuities Case), [1910] A.C. 637 (P.C.), aff'g(1909), 42 S.C.R. 1, rev'g(1907), 10 Ex. C.R. 445. These cases, and their position in Canadian Aboriginal rights jurisprudence are discussed in greater detail in L.I. Rotman, "Provincial Fiduciary Obligations to First Nations: The Nexus Between Governmental Power and Responsibility" (1994) 32 Osgoode Hall L.J. 735 [hereinafter "Provincial Fiduciary Obligations"] and Parallel Paths, supra note 21. Supra note 21.

Ibid. at 54.

46 For example, in St. Catherine's, ibid., the Saulteaux band of Ojibway, whose land interests were the subject matter of judicial deliberation, was not even a party to the proceedings. See also J. Borrows, "Constitutional Law From a First Nation Perspective: Self-Government and the Royal Proclamation" (1994) 28 U.B.C. L. Rev. 1 at 35, n. 130:

The fact that First Nations were not represented or called to testify in a case that purportedly decided their rights shows the depth of exclusion that First Nations experienced in getting their perspectives injected into legal discourse. This is highly regrettable given the wealth of testimony available, since the First Nations people who signed the treaty would still have been available to present their understanding.

In a letter to the Under Secretary of State for War and Colonies in 1824, Sir John Beverly Robinson, later Chief Justice of Upper Canada, illustrated this common characterization:

To talk of treaties with the Mohawk Indians, residing in the heart of one of the most populous districts of Upper Canada, upon lands purchased for them and given to them by the British Government, is much the same, in my humble opinion, as to talk of making a treaty of alliance with the Jews in Duke street or with the French emigrants who have settled in England. 
remained subject to abrogation or elimination by the Crown. ${ }^{48}$ For example, in the Supreme Court of Canada's decision in St. Catherine's Milling, ${ }^{49}$ Taschereau J. held that:

The Indians must in the future ... be treated with the same consideration for their just claims and demands that they have received in the past, but, as in the past, it will not be because of any legal obligation to do so, but as a sacred political obligation, in the execution of which the state must be free from judicial control. ${ }^{\text {so }}$

\section{B. ...ARE HEREBY RECOGNIZED...: TRANSITIONS IN ABORIgINAL RIghtS JURISPRUdENCE}

It was not until the British Columbia Court of Appeal's decision in $R$. v. White and $B o b^{51}$ in 1964 that Aboriginal and treaty rights were once again afforded judicial recognition on their own terms. The White and Bob case marked the re-emergence of Aboriginal rights interpretations according to indigenous legal conceptions. The respondents in the case, members of the Saalequun tribe, were charged with the possession of six deer carcasses during closed season without a valid permit under the British Columbia Game Act. ${ }^{52}$ They claimed that they were guaranteed the right to hunt under an 1854 agreement between their ancestors and Governor James Douglas. Alternatively, they maintained that they possessed an Aboriginal right to hunt on land within traditional Saalequun hunting grounds. At the British Columbia Court of Appeal, Norris J.A. recognized the inherent nature of the Saalequun right to hunt on Aboriginal terms. He described the right as "a very real right ... to be recognized although not in accordance with the ordinary conception of such under British law." 53 In making that determination, he cited Viscount Haldane's judgment in Amodu Tijani. ${ }^{54}$ In a similar vein, Norris J.A. held that Aboriginal treaties, as defined in $\mathrm{s.} 87$ of the Indian Act, ${ }^{55}$ ought to "be given their widest meaning in favour of the Indians" because of the nature of the negotiations leading up to them, and the difference in the cultural understandings

Quoted by Riddell J. in Sero v. Gault (1921), 50 O.L.R. 27 at $31-32$ (S.C. Second Div. Ct.). At least until the entrenchment of treaty rights in s. 35(1) of the Constitution Act, 1982. See, for example, the comments made by Johnson J.A. in R. v. Sikyea (1964), 43 D.L.R. (2d) 150 (N.W.T.C.A.) at 154:

It is always to be kept in mind that the Indians surrendered their rights in the territory in exchange for these promises. This "promise and agreement", like any other, can, of course, be breached, and there is no law of which I am aware that would prevent Parliament by legislation, properly within $s .91$ of the B.N.A. Act, from doing so.

Johnson J.A.'s statement in Sikyea is now subject to the constitutional protection of treaty rights and the justificatory test for the abrogation of those rights instituted by the Supreme Court of Canada's decision in Sparrow, supra note 4. However, the application of the Sparrow test to treaty rights is not without controversy: see L.I. Rotman, "Defining Parameters: Aboriginal Rights, Treaty Rights, and the Sparrow Justificatory Test" (1997) 36 Alta. L. Rev. 149.

(1887), 13 S.C.R. 577.

Ibid. at 649 .

(1964), 50 D.L.R. (2d) 613 (B.C.C.A.) [hereinafter White and Bob].

R.S.B.C. 1960 , c. 160 .

Ibid. at 635 .

Supra note 34.

R.S.C. 1952, c. 149; now S. 88 of the Indian Act R.S.C. 1985, c. I-5. 
of their meaning by Aboriginal and non-Aboriginal parties. ${ }^{56}$ The White and Bob case re-invigorated interpretations of Aboriginal and treaty rights that recognized and affirmed indigenous customs. It was soon to be followed by the equally significant decision in Calder v. British Columbia (A.G.). ${ }^{57}$

In Calder, the Nishga Tribal Council commenced an action against the Attorney General of British Columbia for a declaration that the Aboriginal title to certain lands had never been lawfully extinguished. In considering this application the Calder case reflected the contrasting approaches to Aboriginal land rights found in the previous century's jurisprudence. Judson J. expressed the view that Aboriginal rights were not akin to common law rights and therefore could not be legally enforceable. On the other hand, Hall $\mathrm{J}$. held that Aboriginal rights were legally enforceable and were not dependent upon their similarity to common law rights. He found that the Nishga had "concepts of ownership indigenous to their culture and capable of articulation under the common law." ${ }^{\text {"S8 }}$ Ultimately neither view garnered the support of a majority of the Supreme Court and the case was decided on a different issue. ${ }^{59}$ The courts had not yet developed an interpretive apparatus to allow them to understand Aboriginal difference while simultaneously recognizing important points of overlap.

The Supreme Court of Canada settled upon an appropriate interpretive tool to reconcile indigenous and non-native legal perspectives a decade later in Guerin. ${ }^{60}$ The issues in Guerin revolved around a dispute over the terms of a lease between the Musqueam Indian band, who had surrendered reserve lands for lease, and the

Supra note 51 at 651 . It should be noted, however, that White and Bob did not mark the first recognition of this principle: see, for example, Worcester, supra note 30 at 582; Robinson Treaties (1895), [1896] 25 S.C.R. 434 at 535; Jones v. Meehan, 175 U.S. 1 at 4 (1899). Supra note 6.

Calder, ibid. at 190. Hall J. also states, ibid., that in reviewing prior cases "there is a wealth of jurisprudence affirming common law recognition of Aboriginal rights."

Martland and Ritchie JJ. sided with Judson J. while Spence and Laskin JJ. agreed with Hall J. The case turned on a procedural issue raised by Pigeon $J$. Since the appellants had not obtained a fiat of the Lieutenant-Governor of British Columbia, he held, ibid. at 224, that the court was without jurisdiction to grant a declaration which impugned the Crown's title to the land. Pigeon J. further held, ibid. at 225-26, that it was doubtful that the constitutional validity of pre-Confederation British Columbia legislation which purported to extinguish the Aboriginal title could be made in proceedings instituted against the provincial Attorney General by virtue of s. 129 of the British North America Act, 1867. Section 129 reads:

Except as otherwise provided by this Act, all Laws in force in Canada, Nova Scotia, or New Brunswick at the Union, and all Courts of Civil and Criminal Jurisdiction, and all legal Commissions, Powers, and Authorities, and all Officers, Judicial, Administrative, and Ministerial, existing therein at the Union, shall continue in Ontario, Quebec, Nova Scotia, and New Brunswick respectively, as if the Union had not been made; subject nevertheless (except with respect to such as are enacted by or exist under Acts of the Parliament of Great Britain or of the Parliament of the United Kingdom of Great Britain and Ireland), to be repealed, abolished, or altered by the Parliament of Canada, or by the Legislature of the respective Province, according to the Authority of the Parliament or of that Legislature under this Act. 
Department of Indian Affairs, which negotiated the lease on the band's behalf. ${ }^{61}$ In the course of his judgment, Dickson J., as he then was, held that the existence of Indian title arose as an independent legal interest which predated the assertion of Crown sovereignty in North America. ${ }^{62}$ In arriving at this conclusion the court followed Hall J.'s decision in Calder that Aboriginal land rights were inherent, did not depend upon prior recognition or affirmation by the Crown, and did not need to correspond to traditional common law conceptions of property rights to receive the common law's protection. ${ }^{63}$ Since the nature and existence of Indian title arose from pre-existing indigenous organization and laws, Dickson J. held that Aboriginal rights should not be categorized according to traditional common law rights of property. ${ }^{64}$ Upon reviewing the cases examined in this article, Dickson. J. made the following observation:

It appears to me that there is no real conflict between the cases which characterize Indian title as a beneficial interest of some sort, and those which characterize it a personal, usufructuary right. Any apparent inconsistency derives from the fact that in describing what constitutes a unique interest in land the courts have almost inevitably found themselves applying a somewhat inappropriate terminology drawn from general property law. There is a core of truth in the way that each of the two lines of authority has described native title, but an appearance of conflict has none the less arisen because in neither case is the categorization quite correct. ${ }^{\text {ss }}$

Since conventional common law characterizations of Indian title were inappropriate, Dickson J. devised a more appropriate terminology to describe Aboriginal rights to land. He accomplished this by characterizing Aboriginal rights as sui generis. ${ }^{66} \mathrm{Here}$,

After lengthy negotiations between the Department of Indian Affairs and a private golf club, a large portion of the band's reserve was leased for the band's benefit. However, some of the terms of the lease were different from those disclosed to the band by Indian Affairs during negotiations, or not disclosed to the band at all. Moreover, the band only received a copy of the completed lease twelve years after it had been signed, despite the band's repeated requests to Indian Affairs to obtain a copy of the lease after it had been signed The Musqueam band sued the federal Crown for damages, alleging that the federal Crown was a trustee of the surrendered lands and breached its trust through its conduct in negotiating and signing the lease.

Under the provisions of the Indian Act, supra note 55, Indian bands are prohibited from selling, leasing, or otherwise alienating their interest in land other than to the federal Crown, whose authority over "Indians, and Lands reserved for the Indians," is established in s. 91(24) of the Constitution Act, 1867. After obtaining a surrender of Indian lands, the Crown may sell or lease the land to a third party on behalf of the surrendering band. Supra note 3 at 336.

lbid.

By way of legal fiction, property interests under the common law are said to be derived from the Crown, who holds the land on behalf of the nation. In contrast, Dickson J. wrote that Indian title was "a pre-existing legal right not created by Royal Proclamation, by s. 18(1) of the Indian Act, or by any other executive order or legislative provision" (ibid. at 336).

Ibid. at 339.

The use of the phrase "sui generis" to describe Aboriginal rights was not initiated in Guerin. Previously, it had been used in academic articles to describe Aboriginal rights and the law of Indian treaties: see, for example, C.F. Wilkinson and J.M. Volkman, "Judicial Review of Indian Treaty Abrogation: 'As Long as Water Flows, or Grass Grows Upon the Earth' - How Long a Time Is That?" (1975) 63 Cal. L. Rev. 601 at 612: "Judicial interpretation of Indian treaties has resulted in a legal relationship and a body of law which are truly sui generis"; K.T. Ellwanger, "Money Damages for Breach of the Federal-Indian Trust Relationship After Mitchell Ir" (1983-84) 
at last, was a suitable tool to reconcile the continued existence of a prior Aboriginal legal system with Crown assertions of sovereignty. Categorizing Aboriginal title as sui generis allowed the court to recognize the confluence and co-existence of indigenous and English laws and to protect those rights which flowed from pre-existing indigenous legal regimes.

While the Guerin decision reconciled potentially conflicting judicial assumptions about the existence and nature of Aboriginal title, it also eliminated almost one hundred years of judicial uncertainty about how to conceptualize Aboriginal rights. In addition to describing Aboriginal title as sui generis, Dickson J. also employed the term to describe the unique relationship between the Crown and First Nations, and the obligations that flowed from it. He determined that the historical interaction between the Crown and Aboriginal peoples in Canada was sui generis because the relationship between them developed according to rules derived from both indigenous and English legal regimes. As a result, the unique Crown-First Nations relationship could not be categorized as conferring either exclusive public or private law duties in the strictest sense. Rather, the duties that flowed from this unique legal relationship were themselves sui generis, ${ }^{67}$ and resulted in the creation of legally-enforceable duties upon the Crown. ${ }^{68}$ The Guerin decision was, however, only the beginning of the judiciary's extension of the sui generis concept in Canadian Aboriginal rights jurisprudence.

\section{C. ...AND AFFIRMED: CONTEMPORARY APPLICATION OF THE SUI GENERIS CONCEPTION OF ABORIGINAL RIGHTS}

In the Simon case, which was decided less than a year after Guerin, the Supreme Court further extended and affirmed its applications of sui generis conceptualizations to treaty interpretations. ${ }^{69}$ In that case a member of the Shubenacadie Indian Brook Band (No. 2) was charged with the unlawful possession of a shotgun cartridge and rifle during closed season contrary to s. 150(1) of the Nova Scotia Lands and Forests Act. ${ }^{70}$ At the time he was charged, Simon was travelling on a public highway adjacent to his reserve. Simon insisted that the charge laid against him violated his treaty right to hunt. " Upon appeal to the Supreme Court of Canada, Dickson C.J.C. held that the 1752 treaty was validly created by competent parties and was intended, among other things,

59 Wash. L. Rev. 675 at 687 : “[t]he federal-Indian relationship is, however, sui generis and should not be governed by the common law of trusts - a separate and distinct body of law" [footnote omitted].

67 Guerin, supra note 3 at 341.

68 Such as the solemnity of treaties and the nature and effect of the Crown's fiduciary obligations to Aboriginal peoples.

69 Although Simon, supra note 4, was not the first judicial recognition of the unique nature of Indian treaties in Canada. See, for example, While and Bob, supra note 51 at 617-18; Francis v. The Queen (1956), 3 D.L.R. (2d) 641 at 652 (S.C.C.); Pawis v. The Queen (1979), 102 D.L.R. (3d) 602 at 607 (F.C.T.D.) [hereinafter Pawis]. R.S.N.S. 1967, c. 163.

" Article 4 of a 1752 treaty between Major Jean Baptiste Cope, Chief Sachem of the Mi'kmaq Indians inhabiting the eastern coast of Nova Scotia, and Governor Hopson of Nova Scotia stipulated that "the said Tribe of Indians shall not be hindered from, but have free liberty of hunting and Fishing as usual" (see Simon, supra note 4 at 396). 
to recognize and affirm the existing Mi'kmaq right to hunt and fish. ${ }^{72}$ The treaty was, in his opinion, a positive source of protection against governmental infringements upon Mi'kmaq hunting and fishing rights: "The treaty was an exchange of solemn promises between the Micmacs and the King's representative entered into to achieve and guarantee peace. It is an enforceable obligation between the Indians and the white man."73

Both the appellant and respondent looked to international law principles of treaty termination to argue about whether the treaty had been terminated or limited by subsequent action. Dickson C.J.C. stated that while international legal principles may be helpful by analogy, they were not determinative in Indian treaty matters. ${ }^{74} \mathrm{He}$ held that Indian treaties were unique agreements neither created by nor terminated according to international law. Treaties were sui generis agreements, complete with their own set of interpretive guidelines and principles. ${ }^{75}$ The Chief Justice wrote:

While it may be helpful in some instances to analogize the principles of international treaty law to Indian treaties, these principles are not determinative. An Indian treaty is unique; it is an agreement sui generis which is neither created nor terminated according to the rules of international law. ${ }^{76}$

Dickson C.J.C. recognized that it was not appropriate to apply an unmediated body of international law to Indian treaties because these agreements were also formulated according to indigenous legal principles. They had an indigenous legal source as "the treaty did not create new hunting or fishing rights but merely recognized pre-existing rights."77 Treaties were the product of a fusion of legal systems and thus could not be interpreted parochially by giving preference to one system of law over the other. ${ }^{78}$ The description of treaty rights as sui generis gives effect to the pre-existing occupancy and laws of First Nations while simultaneously respecting these agreements' international legal context.

He also found that the treaty was intended to maintain peace and order in the region.

Ibid. at 409.

Ibid. at 404.

Ibid.

Ibid.

Ibid. at 408.

In addition to directing the judiciary's use of non-Aboriginal legal principles in matters of Aboriginal rights, the Simon case also provided some guidance as to where courts could discover the nature and scope of analogies drawn from First Nations' laws. Dickson C.J.C. implied that analogies taken from First Nations' law would be discoverable in practices that were "reasonably incidental" to the exercise of the right in question. Practices that are implied in Aboriginal or treaty rights must include First Nations' laws because these laws give the practices their meaning. It provided a valuable insight into the scope of what would be protected under those rights. Simon ruled, ibid. at 403, that "those activities reasonably incidental" to the exercise of the right being protected must also be "implicit" in that right. This finding in Simon was explicitly rejected by the majority's judgment in Van der Peet (S.C.C.), supra note 8. See the discussion of this point in L.I. Rotman, "Hunting for Answers in a Strange Kettle of Fish: Unilateralism, Paternalism, and Fiduciary Rhetoric in Badger and Van der Peet," (1997) 8 Constitutional Forum 40 [hereinafter "Hunting for Answers"]. 
The Sioui case, ${ }^{79}$ decided five years later, reaffirmed Simon's holding that Indian treaties are sui generis, but expanded this description to the treaty relationship between the Crown and First Nations. In that case members of the Huron band of the Lorette Indian Reserve had been charged with cutting down trees, camping, and making fires in unauthorized places in a public park in contravention of park regulations. The band members admitted committing these actions but claimed they were practicing ancestral customs and rites protected by a treaty between the band and the Crown signed in 1760. In examining the legal nature of the treaty, the Supreme Court focused upon the relationship between First Nations and the Crown in the period leading up to its signing. Lamer J., as he then was, held that during this period the Crown's relations with Indians were unique; they "fell somewhere between the kind of relations conducted between sovereign states and the relations that such states had with their own citizens." ${ }^{10}$ This sui generis relationship was neither wholly domestic nor international in character, though it was closer to the latter than the former. The relationship was "very close to those maintained between sovereign nations." endeavoured to gain the Indians' favour and secure alliances with them because "the Indian nations were regarded in their relations with the European nations which occupied North America as independent nations." ${ }^{182}$

The Sioui decision is significant because it recognized the sui generis nature of the treaty relationship between European and Aboriginal nations. In particular, it recognized the unique sovereign-like status and independence of First Nations in their capacity to enter into treaties with European nations. While the court fell short of describing First Nations as fully sovereign under international law, its conceptualization of First Nations' sovereignty still drew very strongly from this source. ${ }^{83}$ Furthermore, the recognition that First Nations possessed "sufficient autonomy" to create treaties likewise affirms the role of indigenous legal conceptions in guiding the parties' conduct. ${ }^{84}$ Indigenous law conferred upon First Nations the competence and capacity to enter into treaties, ${ }^{85}$ and these legal precepts intermingled with international law principles to create a sui generis relationship between the First Nation and the Crown. The unique political status of Aboriginal nations in their relationship with the Crown continues to provide interpretive authority to the contemporary meaning of the Crown/Aboriginal relationship.

\section{Supra note 4.}

so Ibid. at 437.

si Ibid. at 448 .

$82 \quad$ lbid.

s See also P.W. Hutchins, "International Law and Aboriginal Domestic Litigation" (1993) Can. Council Int. L. Proc. 11.

84 See Sioui, supra note 4 at 451 , where Lamer J. wrote:

The sui generis situation in which the Indians were placed had forced the European mother countries to acknowledge that they had sufficient autonomy for the valid creation of solemn agreements which were called "treaties", regardless of the strict meaning given to that word then and now by international law.

3s Lamer J.'s reliance upon the United States Supreme Court's decision in Worcester, supra note 30, in which the independent character of Indian nations was explicitly recognized, suggests that the sui generis characterization of Indian political power leaves ample room for a meaningful scope of indigenous law-making power: see, for example, Sioui, supra note 4 at 448-49. 
The Sparrow case, ${ }^{86}$ released the same month as Sioui, constitutionalized a flexible, sui generis interpretation of existing Aboriginal rights and affirmed their existence in a contemporary form to permit their evolution over time. ${ }^{87}$ In dispute was the nature and scope of Aboriginal fishing rights and the Crown's ability to interfere with those rights through legislative initiatives. The appellant, a member of the Musqueam band, was charged under the federal Fisheries $A c t^{88}$ with fishing with a drift net longer than that permitted by the terms of his band's food fishing licence. He admitted using a net longer than the licence allowed, but contended that he was exercising his Aboriginal right to fish under s. 35(1) of the Constitution Act, 1982. He maintained that the legislation was repugnant to his Aboriginal right and that he should not be limited in his right to fish by the legislation since it conflicted with s. 35(1).

The Supreme Court's decision in Sparrow recognized that the Musqueam had an existing Aboriginal right to fish for food, social and ceremonial purposes. ${ }^{89}$ This right was affirmed without resorting to conventional common law categorizations. The Court wrote:

Fishing rights are not traditional property rights. They are rights held by a collective and are in keeping with the culture and existence of that group. Courts must be careful, then, to avoid the application of traditional common law concepts of property as they develop their understanding of ... the "sui generis" nature of Aboriginal rights. ${ }^{90}$

In following its own injunction the Court did not interpret the Musqueam right to fish by reference to traditional property rights. It implicitly recognized that the right flowed from a pre-existing source which necessitated a sensitivity "to the Aboriginal perspective itself on the meaning of the rights at stake." perspective provided it with some guidance on how to give content and meaning to Aboriginal rights by incorporating Aboriginal legal meanings into the common law. ${ }^{92}$ The consideration of Aboriginal legal understandings thus led the court to conclude that the Aboriginal right to fish for food, social and ceremonial purposes existed for reasons connected to their cultural and physical survival, which could be exercised in a

\section{Supra note 4.}

See ibid. at 397.

R.S.C. 1970, c. F-14, s. 61(1).

The Supreme Court of Canada further determined that s. 35(1) afforded Aboriginal peoples with constitutional protection against provincial legislative power, the basis of which was rooted in the precedent established by Guerin. Consequently, legislative initiatives which had the effect of infringing upon Aboriginal rights, such as the right to fish, were invalid unless they passed a justificatory test imposed by the court. That test held that any legislation which interfered with the exercise of an Aboriginal right had to conform to justificatory standards imposed by the Constitution Act, 1982. These standards included the Crown's fiduciary duty to First Nations. Where the legislation failed to meet those standards, it was deemed to be null and void.

Sparrow, supra note 4 at 411 .

Ibid.

The Court's recognition of, and professed sensitivity to, the sui generis nature of Aboriginal rights is belied, however, by the court's assertion early in its judgment that "there was from the outset never any doubt that sovereignty and legislative power ... vested in the Crown" (ibid. at 404). 
contemporary manner. ${ }^{93}$ This sui generis characterization "renounces the old rules of the game under which the Crown established courts of law and denied those courts the authority to question sovereign claims made by the Crown"94 and recognizes the unique source of Aboriginal rights on their own terms. ${ }^{95}$

Finally, in $R$. v. Van der Peet, the Supreme Court made plain its view that Aboriginal rights arise from the traditional laws and customs of Aboriginal peoples. ${ }^{96}$ It suggested that, just as Aboriginal rights cannot be categorized using conventional common law doctrines alone, neither can they be defined using only indigenous legal principles. Their essence is their bridging of Aboriginal and non-Aboriginal legal cultures. As such, the Court found that Aboriginal rights are a "form of intersocietal law that evolved from long-standing practices linking the various communities." 97 This view was supported by drawing from Professor Walters' writings. The Court stated:

The challenge of defining Aboriginal rights stems from the fact that they are rights peculiar to the meeting of two vastly dissimilar legal cultures; consequently there will always be a question about which legal culture is to provide the vantage point from which rights are to be defined...a morally and politically defensible conception of Aboriginal rights will incorporate both legal perspectives. ${ }^{98}$

Therefore, a true sui generis conception of Aboriginal rights will respect the existence within Canada of two vastly different legal cultures, European and Aboriginal, and will incorporate both legal perspectives. A sui generis approach will place "equal weight" on each perspective and thus achieve a true reconciliation between the cultures. Thus, while it "is "crucial to be sensitive to the Aboriginal perspective itself on the meaning of the rights at stake' ... [i]t must also be recognized, however, that that perspective must be framed in terms cognizable to the Canadian legal and constitutional structure."99

The right to fish for food, social and ceremonial purposes was also held by the Supreme Court to form an integral part of Musqueam's distinctive culture. That right was an "existing right" under s. 35(1) and was therefore afforded constitutional protection. The definition of an "existing right" under s. 35(1) is any Aboriginal or treaty right that remained in existence when the Constitution Act, 1982 came into effect on 17 April 1982. Any such right, regardless of the extent to which it had previously been abrogated by governmental regulation, became constitutionally protected in its full force and effect by s. 35(1). 26 Osgoode Hall L.J. 95 at 100.

The Sparrow decision has both been hailed as a positive advance for Aboriginal rights and an illustration of the continuation of colonialist legal theory. On the former point, see the statements of Georges Erasmus, former National Chief of the Assembly of First Nations, Globe \& Mail (1 June 1990) 1, as quoted in W.I.C. Binnie, "The Sparrow Doctrine: Beginning of the End or End of the Beginning?" (1990) 15 Queen's L.J. 217 at 217. On the latter, see Binnie, ibid;; Asch and Macklem, supra note 21. Supra note 8 at 199 (para. 41).

Ibid.

98 Ibid. citing M. Walters, "British Imperial Constitutional Law and Aboriginal Rights: A Comment on Delgamuukw v. British Columbia" (1992) 17 Queen's L.J. 350 at 412-13.

99 Van der Peet (S.C.C.), supra note 8 at 202 (para. 49) [footnote omitted]. 
As each of these cases recognize, Aboriginal rights are both unique and have a lengthy existence in Canadian law. Indeed, these rights stem from prior indigenous legal systems and precede the imposition of Canadian law. Despite this lengthy recognition of inherent Aboriginal rights, and their unique character, it was not until Guerin that their sui generis nature received explicit judicial attention. Since that time, the judiciary has extended its application of sui generis Aboriginal rights from land rights to Indian treaties, hunting and fishing rights, the Crown-Aboriginal fiduciary relationship, cultural property, and finally, all Aboriginal rights. The gradual recognition of the sui generis nature of Aboriginal rights was accompanied by an increasing focus upon the need to consider Aboriginal perspectives on the meaning of these rights. The reception of indigenous legal perspectives as a source in Aboriginal rights jurisprudence takes the emphasis away from the Crown and European-derived law, and replaces them with a more Aboriginal-centred focus. This is appropriate given that we are dealing with the fundamental rights and freedoms of Aboriginal people. That said, it remains open to question the effects of the characterization of Aboriginal and treaty rights as sui generis both on Aboriginal people and upon juridical pronouncements on those rights.

\section{The Paradox, Purpose and Content of SuI Generis Rights}

The sui generis formulation of Aboriginal rights presents an acute paradox for Aboriginal peoples. Using this concept introduces potential problems on at least two levels. Aboriginal peoples initially have to confront the notion that using sui generis principles may mean relinquishing control of their legal system and rights to another culture's laws. This is the dilemma surrounding Aboriginal peoples' preservation of their sovereignty in their interaction with Canadian law, or what will be described as the "external challenge" of the sui generis principle. A second related consideration is that even if Aboriginal people find evidence that they do not surrender their sovereignty by using the common law system, there may be disadvantages within the common law system itself in describing rights as sui generis. The Aboriginal people may lose their claims despite the potential of the sui generis doctrine. This is the challenge that any litigant faces within the common law, or what will be described as the "internal challenge" of the sui generis doctrine. This section examines both of these issues to determine whether Aboriginal peoples can overcome the external and internal challenges that the sui generis doctrine presents.

\section{A. The Sui generis Principle: The External Challenge}

The sui generis concept is employed to discard those notions of the common law that have not been "sensitive to the Aboriginal perspective itself on the meaning of the rights at stake." ${ }^{\prime 100}$ As such, the doctrine can be characterized as a part of the common law - that attempts to leave behind much of the common law. Such a selective invocation of the common law is a risk-laden speculation for Aboriginal peoples. If they submit to even a part of the common law, it is inevitable that the other parts of this structure will continue to operate. A contextual shift in one doctrine does not mean 
that the accompanying legal blueprint will be redrafted to conform to the new principle. ${ }^{101}$ There is still an intricate system in place that supports the old design and architecture of the law. ${ }^{102}$ Since the past application of common law principles has restricted Aboriginal peoples in the exercise of their original entitlements, its further use could represent the continuation of colonialism's design. ${ }^{103}$ Why should there be any faith that the common law's destruction of Aboriginal nations will be reversed by the application of sui generis concepts? Could this be yet another instance of a futile use of the "master's language and conceptual apparatus to dismantle the master's house?"104

In considering the categorization of Aboriginal rights as sui generis, these questions, and a number of others, should be asked. Can common law tools be re-forged to accommodate Aboriginal cultures and refashioned to suit purposes for which they were not initially designed? Will these changes occur solely within the courts, without associated changes to Aboriginal power in the political, social and economic terrain? If it is possible that Aboriginal peoples can change the master's language and re-work its associated conceptual apparatus, what will these new tools look like? In such remaking are they still the master's tools, or can the Aboriginals claim some creation and ownership of them? Even under Aboriginal ownership, would these be the sort of implements needed to accomplish Aboriginal objectives? The courts' development of a sui generis conception of Aboriginal rights contains partial answers to these questions.

As outlined in the cases, the courts have sited a small, but perceptible, clearing in the common law for Aboriginal conceptions of their rights. This means that courts are no longer tightly bound by conventional common law notions in giving meaning and force to the right being disputed. They have more freedom to consider the history, content and meaning of Aboriginal rights outside of the common law's own cultural context. Such a technique partially insulates Aboriginal rights from the corrosive effects of the common law. It also allows different cultural practices to be interpreted more fully on Aboriginal terms.

For a description of how common law systems resist change despite the introduction of Aboriginal rights in s. 35 of the Constitution Act, 1982, see K. McNeil, "Envisaging Constitutional Space for Aboriginal Governments" (1994) 19 Queen's L.J. 95.

For example, despite the presence of sui generis principles, the rules of evidence still operate at the same facially-neutral level, with the result that they disregard cultural difference in their interpretation and application to First Nations. See C. McLeod, "The Oral Histories of Canada's Northern People, Anglo-Canadian Evidence Law, and Canada's Fiduciary Duty to First Nations: Breaking Down the Barriers of the Past" (1992) 30 Alta. L. Rev. 1276.

Colonialism's design for First Nations is illustrated in Duncan Campbell Scott's statement that "Our object is to continue until there is not a single Indian in Canada that has not been absorbed into the body politic, and there is no Indian question, and no Indian Department," as quoted in J.R. Miller, Skyscrapers Hide the Heavens: A History of Indian-White Relations in Canada (Toronto: University of Toronto Press, 1989) at 207, and implemented by the Indian Act, supra note 61.

M.E. Turpel, "Aboriginal Peoples and the Canadian Charter: Interpretive Monopolies, Cultural Differences" (1989) 6 Cdn. Hum. Rts. Y.B. 3 at 6, citing A. Lorde, "The Master's Tools Will Never Dismantle the Master's House" in A. Lorde, Sister Outsider (Trumansburg, N.Y.: The Crossing Press, 1984). 
However, the sui generis translation of Aboriginal rights at once avoids and reinforces the problem of rendering common law concepts in terms that are inappropriate to Aboriginal systems which have grown up under another law. While sui generis definitions forge tools to raise Aboriginal conceptions of rights, this edifice is constructed on common law domain. Thus, while the doctrine may avoid hammering the square pegs of indigenous laws into the round holes of conventional legal categories, ${ }^{105}$ its use reinforces the larger common law system with all of its associated improprieties. For Aboriginal people, it may not matter that a few pegs are made to fit, if the territory on which the house is being erected is the wrong one.

Aboriginal peoples working with the common law must always keep these paradoxes in mind. Most Aboriginal nations are not attempting to build communities that reside within physically foreign and legally alien territories. Rather, they are seeking a patriation of their spiritual, cultural and institutional homelands. Clearing a site in the common law that respects Aboriginal perspectives only serves the limited purpose of providing a toehold to bridge out of colonial territory into one they can call their own. Therefore, finding this place in the common law does not represent a consent to colonialism. The use of sui generis principles within the common law pours footings for a bridge that permits an exit from colonialism's hostile and confining thicket.

In employing this application of law, Aboriginal people only want to dismantle that part of the master's house that keeps them incarcerated. ${ }^{106}$ It is not necessary to tear down the entire house. Indeed, it is not appropriate to do so because others are still living in it. ${ }^{107}$ Such actions would be inconsistent with treaties of peace, friendship and

In "Aboriginal Self-Government and the Crown's Fiduciary Duty: Squaring the Circle or Completing the Circle?" (1993) 2 N.J.C.L. 163 at 185, Alan Pratt commented on the importance of finding an unique foundation for Aborigina//Crown relationships:

There is little doubt in my mind that the tension between the ideas of Locke and Hobbes continue to govern our thinking. I believe that the truth of the matter requires us to acknowledge that the relationships between the Aboriginal peoples and the civilization created by immigrant peoples cannot be simplified into one or other of these paradigms. Those relationships, like all human relationships, are complex and shifting. They will not tolerate being shoved like square pegs into round holes.

Georges Erasmus, the former Chief of the Assembly of First Nations has stated:

We don't want to scare Canadians with our terminology. No one is scared in this country by the fact that Ontario or Manitoba can make laws in education.... They are sovereign in their area of jurisdiction. We, likewise, want to have clear powers over our territories.

G. Erasmus \& J. Sanders, "Canadian History: An Aboriginal Perspective" in D. Engelstad \& J. Bird, eds., Nation to Nation: Aboriginal Sovereignty and the Future of Canada (Concord, Ont: Anansi Press, 1992) at 11. For a contrary view see B. Michel, Band Council Member, Shesatshit First Nation, in F. Cassidy, ed., Aboriginal Self-Determination (Lantzville, B.C.: Oolichan Books, 1991) at 40:

If you want Canada to understand you and your right to self-determination, then that is what you must destroy in Canada. The economic stability that is within Canada. 
respect. ${ }^{108}$ The Gus-Wen-Tah, or Two-Row Wampum, directs each nation to honour these principles. ${ }^{109}$ If this path of respect is not followed, and Aboriginal people attempted to destroy the existing common law and constitutional structure, this would replicate the very effect of colonialism that has been so detrimental to indigenous peoples and cultures. Aboriginal people have long held, in seeking an end to colonialism, that they are not seeking an end to Canada. Rather, they are merely looking to end the injustice they encounter within Canada. Ovide Mercredi, former Grand Chief of the Assembly of First Nations, has stated:

For 125 years or more our people have been subjected to something called parliamentary sovereignty or rule of law. These are important concepts for any society because they maintain order and harmony amongst people. But when they exclude the basic rights and the fundamental freedoms of another society, then these concepts become oppressive - and that is how the laws have been made by Parliament and legislatures across this land. They were not designed to oppress us but the end result has been oppression. And the reason why laws can be made without regard to our rights and freedoms is because a supreme law is silent on our rights and freedoms. And if we can modify it in a most fundamental way, we have the potential of not just the healing and recovery of our own nations as indigenous people, but we also have the potential of transforming Canada as a society that would receive our peoples as individuals on an equal basis. ${ }^{1 t 0}$

This statement represents the feeling of most Aboriginal nations and their desires to be respected in law. They do not want to completely dismantle Canada. They simply want to redesign it to more closely address their needs and have it reflect their position in Canadian society. ${ }^{11}$ Non-native scholars have similarly recognized that Aboriginal

Such as the Treaty of Albany, 1664, the Covenant Chain alliance, and the various Maritime peace and friendship treaties between the Crown and Aboriginal peoples in the late seventeenth and eighteenth centuries. The Treaty of Albany was the first formal treaty between the British and Native peoples: see writings dated 24 September 1664 in "Articles between Col. Cartwright and the New York Indians" in E.B. O'Callaghan, ed., Documents Relative to the Colonial History of the State of New York, vol. 3, (Albany: Weed, Parsons, 1853-61) at 67-68.

The Two-Row Wampum, presented to the British at the signing of the Treaty of Albany, 1664, indicates the understanding that each nation would relate to the other through principles of peace, friendship, and respect, while maintaining their own separate but parallel paths. The Gus-Wen-Tah has been described as follows:

There is a bed of white wampum which symbolizes the purity of the agreement. There are two rows of purple, and those two rows have the spirit of your ancestors and mine. There are three beads of wampum separating the two rows and they symbolize peace, friendship, and respect. These two rows will symbolize two paths or two vessels, travelling down the same river together.... We shall each travel the river together, side by side, but in our own boat. Neither of us will try to steer the other's vessel.

R.A. Williams Jr., "The Algebra of Federal Indian Law: The Hard Trail of Decolonizing and Americanizing the White Man's Indian Jurisprudence" (1986) Wisc. L. Rev. 219 at 291 . See also the discussion of the Treaty of Albany in Parallel Paths, supra note 21. Services Canada, 1992) at 34.

i1I Therefore, the question is not whether you can use the master's tools to dismantle the master's house. Rather, the question is can you use the master's tools to redesign the master's house. Many Aboriginal people use the common law to redesign it to include an exit which allows them to control many of their own affairs. See the litigation strategy of the Assembly of First Nations in their intervention in Sioui, supra note 4, in F.S. Gerler \& P. Hutchins, "Documents - R. v. Siour" 
people are not seeking the destruction of Canada, but its improvement through the recognition of their rightful place within it:

I find in the statements of virtually all Aboriginal leaders that the objective of their position is to achieve recognition of their sovereignty and not to overturn the sovereignty of the Canadian state.... Aboriginal nations are not intent on seeking to destroy Canada or devalue non-Aboriginal people, but rather to ensure recognition of their rightful place as co-founders of this nation. ${ }^{112}$

Using the common law without dismantling its underlying structure does not mean that Aboriginal people are forever trapped and further entwined in the very structure they are trying to escape. Much, if not most, of Aboriginal peoples' life and experience will continue to go on without much reference to the common law, as it has throughout the worst years of colonization. ${ }^{113}$ For the most part, Aboriginal people will continue to be guided by their own teachings and systems of laws. They have a proud legacy of resistance and survival that has endured through more extreme examples of the law's interference. ${ }^{114}$ If they can survive as peoples through explicit policies of assimilation, ${ }^{115}$ racism, ${ }^{116}$ and cultural genocide, ${ }^{117}$ surely they will not be overwhelmed by securing a place in the common law where a greater departure from its constraints can be made.

Additionally, Aboriginal people have a further reason to conclude that they can escape the most encumbering canons of the common law. The sui generis concept finds its basis in "traditional laws and customs" found in the "pre-existing societies of Aboriginal peoples," and in their interaction with the common law. ${ }^{18}$ This means that under sui generis reformulations the legal territory being "set apart" and "reserved" to protect Aboriginal interests is a place where Aboriginal people have a continuing, unextinguished legal interest. In this system, conventional common law analogies have force only to the degree that they can be reconciled with the "tradition, custom, practice or law" of the Aboriginal group claiming the right. ${ }^{119}$ As such, this sui generis territory allows for the expression and protection of Aboriginal rights that existed prior

(1990) 6 Native Studies Review 115-50.

M. Asch, "Aboriginal Self-Government and the Construction of Canadian Constitutional Identity" (1992) 30 Alta L. Rev. 465 at 490-91.

See D. Cole \& I. Chaikin, An Iron Hand Upon Our People (Vancouver: Douglas \& McIntyre, 1990) for a description of how the potlach continued to exist despite the law's non-recognition. See also the earlier discussion of Johnson, supra note 28; J.C. Smith, "The Concept of Native Title" (1974) 24 U.T.L.J. 1.

For an example of the continuing existence of First Nations' powers in one community, see Borrows, "A Genealogy of Law," supra note 18.

J. Tobias, "Protection, Civilization, Assimilation: An Outline History of Canada's Indian Policy," in I.A.L. Getty \& A.S. Lussier, eds., As Long as the Sun Shines and Water Flows: A Reader in Canadian Native Studies (Vancouver: University of British Columbia Press, 1983) at 39.

See R.A. Williams Jr., The American Indian in Western Legal Thought: The Discourses of Conquest (New York: Oxford University Press, 1990).

E. Robinson \& H.B. Quinney, The Infested Blanket: Canada's Constituiton - Genocide of Indian Nations (Winnipeg: Queenston House, 1985).

Van der Peet (S.C.C.), supra note 8 at 198 (para. 40).

R. v. N.T.C. Smokehouse Ltd., [1996] 4 C.N.L.R. 130 at 138 (para. 14) (S.C.C.). 
to, and independently of, the common law. ${ }^{120}$ This ground rejects interpretations premised on conventional categories of the common law that have no reference to Aboriginal practices and experiences. The contemporary preservation and expression of these laws and traditions in their interaction with the common law institutionally preserves the very essence of Aboriginal communities.

Since the jurisdiction for recognizing sui generis principles has its foundation in continuing traditional Aboriginal law and practice, this should provide an indispensable role for Aboriginal people in the contemporary expression of their rights. In such a scheme, Aboriginal people become a fundamental reference point to arrive at sui generis interpretations because they are the ones best acquainted with the meaning of the rights in question. ${ }^{121}$ To ensure that Aboriginal perspectives are incorporated into law, the sui generis doctrine requires that the judiciary respond to Aboriginal notions of their laws and practices. ${ }^{122}$ Thus, while there should be a healthy skepticism about the common law's ability to express pre-existing Aboriginal rights, sui generis reformulations may assist in the assertion of Aboriginal principles against inappropriate common law intrusions. This should facilitate a disentanglement from the worst elements of common law suppression, even though this approach leaves much of the underlying structure of the common law intact.

Despite this potential, some may still question whether the overwhelming power and ideology of the common law will prevent Aboriginal people from escaping its worst constraints. ${ }^{123}$ There is no question that "western" bias within the law will continue to restrain Aboriginal rights. This should remain a clear cause for great concern. However, it must also be remembered that Aboriginal peoples' attempts to dismantle colonialism are not occurring in a vacuum. ${ }^{124}$ Political pressure, economic development, social recovery and the grass-roots practices of Aboriginal rights are more effective than "the law" in creating the conditions for liberation. In fact, without this more direct action,

Guerin, supra note 3 at 335.

This fact is recognized in cases which indicate the need for the Crown to consult with the Aboriginal peoples. See, for example, Sparrow, supra note 4 at 416-17; Eastmain Band v. Canada, [1993] 3 C.N.L.R. 55 at 63 (F.C.A.); New Zealand Maori Council v. Attorney-General, [1987] 1 N.Z.L.R. 641 at 665 (N.Z.C.A.).

Sparrow, supra note 4 at 411.

J. Bakan, "Constitutional Interpretation and Social Change: You Can't Always Get What You Want (Nor What You Need)" (1991) 70 Can. Bar Rev. 307.

As MacKinnon A.C.J.O. stated in R. v. Taylor and Williams (1981), 62 C.C.C. (2d) 227 at 232

(Ont. C.A.) [hereinafter Taylor and Williams]:

Cases on Indian or Aboriginal rights can never be determined in a vacuum. It is of importance to consider the history and oral traditions of the tribes concerned, and the surrounding circumstances at the time of the treaty, relied on by both parties, in determining the treaty's effect.

We would argue that this same observation applies when interpreting the effect on Aboriginal values of current assertions of Aboriginal rights in the courts. To gain a fuller understanding of the effect of rights being asserted in the courts, it is important to consider the contemporary circumstances and oral testimony, outside the court, at the time the right is being propounded. One will notice Aboriginal people engaging in much greater activity outside, than inside, the courts. This places in proper context the de minimis effect of the common law on Aboriginal legal/cultural values. 
associated common law gains will not be realized. Aboriginal rights arise from Aboriginal customs and practices, they do not originate from a grant of power by the common law. ${ }^{125}$ The common law's role in facilitating the exercise of Aboriginal rights is to clear a path for the contemporary exercise of their continuing traditions. It can do this by judging Aboriginal rights, not by inappropriate common law doctrines, but according to a set of rules more accommodating of Aboriginal cultural principles. Therefore, remembering that the first paradox Aboriginal people encounter in using sui generis principles is the potential that their rights will be controlled by another culture's legal system, it can be seen that this is mediated through the preservation of indigenous legal principles in their interaction with Canadian law.

\section{B. SUI GENERIS ABORIGINAL RIGHTS WITHIN THE COMmon law: The INTERNal Challenge}

Having determined that the common law can play a role in clearing a place for Aboriginal people to express their legal understandings, we now turn to the question of the specific advantages and disadvantages within the common law of labelling Aboriginal rights as sui generis. This examination comes in response to the consideration that, even if Aboriginal people are able to preserve their sovereignty when using the common law, there still may be disadvantages within the common law system itself in describing rights as sui generis. ${ }^{126}$

One difficulty encountered within the common law concerns the degree of protection that Aboriginal rights will be given by being characterized as sui generis. While this description avoids the application of traditional common law concepts, there is no guarantee that other equally inappropriate concepts will not inform their definition. An absence of interpretive standards in the initial framing of the doctrine leaves it vulnerable to influences from inappropriate sources. Some of the court's fragmentary explanations of the doctrine provide little more guidance than a statement that common law and international law notions are simply analogous, or an aid, to understanding sui generis principles. Yet, the idea that sui generis rights are at times analogous to other systems of law does not tell judges when, or how, to strike such analogies, and when to dismiss them. Presently, there are very few standards to direct sui generis applications.

The interpretation of sui generis rights without reference to clearer standards leaves judges with too much discretion, especially when most do not understand indigenous legal principles and perspectives. As such, the real extent of the protection afforded by descriptions of Aboriginal rights as sui generis may be rendered entirely dependent

The common law does not generally create rights for First Nations, as the last 150 years of its application to their communities has shown.

126 The authors recognize that dividing the external from the internal implications of using the sui generis doctrine is artificial. Obviously any internal failings within the common law of invoking the sui generis doctrine could have major drawbacks for the preservation of the external pre-existing rights of Aboriginal people. The distinction is made merely to focus attention on how the systemic challenge of the common law operates at a different level from those encountered within its internal workings. 
upon the goodwill of the judiciary. ${ }^{127}$ Being dependent on the goodwill of the judiciary is likely no better protection than being "dependent on the goodwill of the Sovereign," formulated in St. Catherine's Milling and Lumber Co. v. The Queen. ${ }^{128}$ Without more concrete interpretative tools, there is a real danger that the undefined nature of Aboriginal rights as sui generis creates a situation where discretion is merely shifted from one institution to another within the colonial structure.

Under the common law, where Aboriginal rights are described primarily in terms of Aboriginal property rights, there are well developed standards that identify Aboriginal rights as, at a minimum, a burden upon the Crown's underlying title. ${ }^{129}$ Under sui generis formulations, Aboriginal people do not even potentially have this severely limited protection because, at the outset, the courts have said very little about the nature of the sui generis interest in land. Consequently, while the characterization of Aboriginal property rights as "burdens" upon "superior" Crown rights is not one which Aboriginal people agree with, it is, at least, a legally-recognized interest. ${ }^{130}$ Currently, the sui generis category is an "empty box," 131 which has yet to be filled with substantive procedures and protections Aboriginal rights. Ian Binnie has noted the absence of definition or guidance in sui generis formulations:

[T]he more recent description (really a non-description) of Aboriginal rights as sui generis is wholly the creation of our own Supreme Court. The description, first coined in Guerin, has been repeated in

This observation has been noted in another setting relating to the judicial interpretation of Aboriginal peoples' constitutional rights. See S. Grammond, "Aboriginal Treaties and Canadian Law" (1994) 20 Queen's L.J. 57 at 81:

[Section 35 rights] are subject to a justification analysis; if they meet the criteria established by the Supreme Court in $R$ v. Sparrow, their validity will be upheld. Thus, the real extent of the protection afforded by $\mathrm{s} .35$ is rendered dependant upon the goodwill of the judiciary [footnote omitted].

\section{lbid. at 54.}

A similar situation occurred in 1969, with First Nations' reactions to the Government of Canada's response to the "Indian problem," the Statement of the Government of Canada on Indian Policy, 1969 (Ottawa: Queen's Printer, 1969), better known as the "White Paper," which recommended, among other things, the elimination of Aboriginal peoples' special status, including the repeal of the federal Indian Act. While First Nations did not necessarily endorse the Indian Act, it was, at the very least, a recognition of their unique status in Canada and of their rights. Therefore, it was deemed better to work with the structure of the Indian Act intact, despite its deficiencies, rather than having nothing which recognized First Nations' special status. On opposition to the White Paper, see Indian Chiefs of Alberta, Citizens Plus (Edmonton: Indian Association of Alberta, 1970), also known as the "Red Paper."

The "full-box/empty box" terminology comes from the discussions of the meaning of s. 35 (1) of the Constitution Act, 1982. In the course of the First Ministers' Conferences on Aboriginal Constitutional Matter from 1983 to 1987 it became clear that the federal Department of Justice saw s. 35(1) as an "empty box." Section 35(1) was likened to a box of rights but the box was empty. When asked to suggest one right that he thought was in s. 35(1), Mr. Ian Binnie, then with the Department of Justice, suggested "the right to surrender land." The response from First Nations leaders was to declare that the box was full. See D. Sanders, "Is Bingo in the Box?" Success Aboriginal Gaming in Canada Conference (Vancouver: Native Investment and Trade Association, 1992) [unpublished]. 
subsequent cases as if repetition will make it into a definition as opposed to an adamant refusal to essay a definition. ${ }^{132}$

Since there are currently few articulated standards for the treatment of sui generis rights, there exists the real danger that Aboriginal rights may receive even less protection under this categorization than with conventional categories of the common law.

That Aboriginal rights could receive even less protection under their sui generis categorization seems almost inconceivable, given the minimal protection offered by the old rules. While the prospect of Aboriginal rights receiving less protection than at present seems outrageous, this is a real possibility. As Binnie has written:

At least some of those who control the federal and provincial treasuries may welcome Sparrow's ringing affirmation of sui generis Aboriginal and treaty rights in terms of iron clad guarantees of mere economic subsistence. ${ }^{133}$

As Binnie implies, there is a chance that sui generis characterizations of Aboriginal rights will merely freeze these rights at the point of contact between First Nations and the Crown, notwithstanding the Supreme Court of Canada's explicit rejection of frozen rights theory in Sparrow. ${ }^{134}$ The effect of interpreting Aboriginal rights in a way that limits their recognition to pre-contact practices will only provide "iron clad guarantees" of very narrow and restricted rights. It is arguable that this has already happened with the court's development of the "integral to a distinctive culture test" in Van der Peet. ${ }^{135}$

In the Van der Peet case, Van der Peet, a member of the Sto:lo nation, was charged with selling salmon under an Indian food fishing licence. ${ }^{136}$ At issue was whether the Aboriginal right to fish, under which she admittedly caught the fish, included the right to barter or sell the fish. At trial, she was convicted and fined $\$ 50$. The trial judge ruled there was no Aboriginal commercial right to fish because of the adverse impact such a right would have on the fisheries and non-Indians' use of it. ${ }^{137}$ On first appeal, Selbie J. of the British Columbia Supreme Court held that the Aboriginal right to fish

132 Binnie, supra note 95 at 221-22 [footnotes omitted]. Binnie did modify the cynicism of his statement somewhat by observing that the court does give some guidance to sui generis formulations: "Occasionally there are poetic hints about the Court's thinking, as in Justice Dickson's comments in Kruger v. R. (1977), 75 D.L.R. (3d) 434 at 437 (S.C.C.) [hereinafter Kruger] that "Claims to Aboriginal title are woven with history, legend, politics and moral obligations."” Ibid. at 241.

For a critique of the Van der Peet test see J. Borrows, "The Trickster: Integral to a Distinctive Culture" (1997) 8 Constitutional Forum 29 [hereinafter "The Trickster"]; Rotman, "Hunting for Answers," supra note 78. 
included the right to sell or barter the catch. ${ }^{138}$ On further appeal to the British Columbia Court of Appeal, the majority held that the Aboriginal right to fish did not include fishing for commercial purposes. ${ }^{139}$ It found that commercial fishing was not a protected Aboriginal right because it had not been integral to Sto:lo society and its distinctive culture prior to the arrival of Europeans, but became prevalent merely as a result of their influences after contact. ${ }^{140}$ The majority's emphasis on unique pre-contact activities of Aboriginal peoples as defining Aboriginal rights endorses Binnie's abovequoted prediction that the sui generis formulation of Aboriginal rights might become an "iron clad guarantee to economic subsistence."

The Supreme Court of Canada did not alleviate this hazard in categorizing Aboriginal rights as unique. Lamer C.J.C. chose to highlight the sui generis nature of Aboriginal rights on the same narrow basis as the British Columbia Court of Appeal. He found that "in order to be an Aboriginal right an activity must be an element of a practice, custom or tradition integral to the distinctive culture of the Aboriginal group claiming the right."141 He further held that these activities must have existed prior to the arrival of Europeans and not have arisen solely as a response to European influence. ${ }^{142}$ The application of this test left Van der Peet without an Aboriginal right to sell or exchange fish because pre-contact Sto:lo trading practices did not take place

[1991] 3 C.N.L.R. 161 (B.C.S.C.). In this case, Selbie J. held that there was no express language extinguishing the Aboriginal right to sell fish for commercial purposes. He further held that the right existed as follows: 1) Originally Indians could do anything they wanted with the fish they caught; 2) eventually their rights became hedged in as their customs developed; 3 ) then their own customs changed as they had contact with settlers; 4) since Aboriginal rights are not frozen they must be able to change their way of using fish (which included selling their fish), as times change; and 5) therefore, First Nations can sell fish as an Aboriginal right.

139 [1993] 5 W.W.R. 459 (B.C.C.A.) [hereinafter Van der Peet (B.C.C.A.)]. In a strong dissent Lambert J.A. rejected the majority's approach as perpetuating a "frozen rights fallacy." He asserted that Aboriginal rights continually evolve, and that new Aboriginal rights may have arisen after the time of contact. Lambert J.A. based his judgment in a description of Aboriginal rights which defines those rights by their relation to the significance of the custom in the lives of the Aboriginal people in question. By tying the determination of Aboriginal rights directly to their significance to the Aboriginal people in question, Lambert J.A. found that commercial fishing must be an Aboriginal right insofar as it was socially important to the continued viability of Sto:lo culture. He found that since the right to sell fish was not extinguished by the fishery regulations on the strength of the Supreme Court of Canada's finding in Sparrow, supra note 4, it is an existing Aboriginal right. Lambert J.A.'s dissent demonstrates that Macfarlane J.A.'s characterization of Aboriginal rights as rights integral to their society before European contact restricts their development to a narrow range of artificial practices which bear no relation to the needs of Aboriginal peoples in the contemporary sustenance of their societies.

Ibid. at 470-73. In arriving at this conclusion, Macfarlane J.A. found that it was relevant that at the time of contact the Sto:lo people fished for food and ceremonial purposes, and not to supply a market. Thus, when the Sto:lo began to sell fish to white settlers, he held that this was not a natural progression of an Aboriginal right. Since Macfarlane J.A. regarded the sale of fish as being induced and driven solely by European influences, he found that it was "clearly different in nature and quantity from Aboriginal activity." He held that the interpretation of Aboriginal rights made it necessary to separate recent practices, which were not a unique part of Indian cuiture and were common to Indian and non-Indian alike, from long-time Aboriginal practices which, as a result of their "time depth," are integral to their culture.

142 Ibid. at 205 (para. 60), 209-10 (para. 73). 
"in any regularized or market sense"143 and thus were not integral to their distinctive culture. Quite simply, the right was found not to exist because trade in salmon prior to contact "did not take place on a basis widespread enough to suggest that the exchange was a defining feature of Sto:lo society"144; Sto:lo trade was not sufficiently "unique" or "distinctive" to make the culture what it was. ${ }^{145}$

The Supreme Court's narrow focus on what constitutes a unique culture removes its attention from sui generis formulations that consistently had their basis in the continued existence of prior legal systems within Canada and the contemporary legal conceptions these generate. As such, the Court has departed from exploring how Aboriginal rights have come to exist within the common law and, instead, overly concentrated on who holds the right as grounding their existence. They have founded the existence of Aboriginal rights in Aboriginality. ${ }^{146}$ Yet, Aboriginal rights are not sui generis merely because they are held by Aboriginal people. ${ }^{147}$ As this article has shown in some detail, Aboriginal rights are sui generis because Aboriginal peoples have laws, traditions, customs, and practices which have developed, grown, changed - and been invented - as Aboriginal people have struggled for physical and cultural survival in North America. This dynamic accounts for the existence of Aboriginal rights. A displaced focus on Aboriginality as defining those rights is inconsistent with this earlier focus. The Court must not define Aboriginal rights solely by notions of who and what they regard as Aboriginal. Yet the Court's test - based on what was, once upon a time, integral to indigenous cultures - does just that. In the process the test draws on inappropriate racialized stereotypes of Aboriginal peoples by attempting to distil the essence of Aboriginality by reference to their pre-contact activities. This caricature presupposes that Aboriginal peoples and their legal systems did not develop in response to European influences, and it freezes them at the point of contact. ${ }^{188}$ This holding is as inappropriate as the application of any conventional common law doctrine the sui generis characterization was designed to replace. Such an approach highlights the dangers within the common law of using sui generis formulations to describe and

Ibid. at 213, quoting from Scarlett P.C.J., supra note 137 at 160.

Ibid. at 215.

Ibid. at 209.

Lamer C.J.C. wrote:

The task of this Court is to define Aboriginal rights in a manner which recognizes that Aboriginal rights are rights but which does so without losing sight of the fact that they are rights held by Aboriginal people because they are Aboriginal.

Van der Peet (S.C.C.), supra note 8 at 190 (para. 20).

See P. Macklem, "Normative Dimensions of an Aboriginal Right of Self-Government" (1995) 21 Queen's L.J. 173, for a discussion of reasons for the existence of Aboriginal rights in Canada. It should be noted that the thrust of this article was taken out of context by the Court in Van der Peet (S.C.C.), supra note 8 at 199 (para. 41).

See J. Borrows, "Frozen Rights in Canada: Constitutional Interpretation and the Trickster" (1997)

$22 \mathrm{Am}$. Ind. L. Rev. (forthcoming); Borrows, "The Trickster," supra note 135; J. Borrows, "Fish and Chips: Aboriginal Commercial Fishing and Gambling in the Supreme Court of Canada" (1996) 50 Criminal Reports 230; L.I. Rotman, "Hunting for Answers," supra note 78; L.I. Rotman, "Aboriginal Rights Law, Year in Review: The 1995-96 Term" (1997) 12 J. L. \& Social Pol'y 34. 
protect Aboriginal rights. ${ }^{149}$ The courts are free to use their discretion to fill in the meaning of sui generis rights without being disciplined by firmer interpretive principles or categories of law in making these applications.

\section{Meeting the SUI Generis "Challenge"}

Professor Aviam Soifer has written, in the context of Aboriginal rights jurisprudence, that "Indian tribes have been deeply, tragically sui generis. The Justices attempted to float free, using only a flimsy syllogism." 150 This article has suggested an approach that would help remedy this situation by providing greater guidance in the characterization of sui generis Aboriginal rights. The principles herein identified are apparent in the jurisprudence but remain dormant because of the difficulty in rejecting the "old rules of the game" which have previously determined these issues. A refocused vision that appropriately considers the principles outlined in this article would include an awareness of the paradoxes and promise Aboriginal peoples experience in using the common law. The key to this approach is to understand Aboriginal rights by reference to the perspectives and laws of the Aboriginal peoples who exercise them. ${ }^{151}$ The point here is that Aboriginal people have contemporary traditions, customs, practices and laws, which ensure their continued "cultural and physical" 152 survival as peoples. ${ }^{153}$ These legal principles and/or the perspectives they generate should find a firmer place in Aboriginal rights jurisprudence.

Western principles of law, and their overly specific and individualized perspectives, should not be the only concepts that guide judges in determining the meaning of Aboriginal rights. Since the sui generis nature of Aboriginal rights flows from their intersocietal nature, ${ }^{154}$ contemporary Aboriginal legal principles and perspectives should be embraced as part of the law relating to Aboriginal rights. The explicit reception of Aboriginal perspectives and principles more firmly establishes an autonomous body of law which bridges Aboriginal and non-Aboriginal legal cultures, ${ }^{155}$ creates an important

For an application of this argument in relation to Aboriginal title see $\mathrm{K}$. McNeil "The Meaning of Aboriginal Title" in M. Asch, ed., Aboriginal and Treary Rights in Canada: Essays on Law, Equality, and Respect for Difference (Vancouver: U.B.C. Press, 1997) 135.

See A. Soifer, "Objects in Mirror are Closer Than They Appear" (1994) 28 Geo. L. Rev. 533 at 540.

Sparrow, supra note 4 at 411 .

lbid. at 402.

See J. Borrows, “With or Without You: First Nations' Law (in Canada)" (1996) 41 McGill L.J. 629 [hereinafter "With or Without You"].

Brian Slattery has observed the application of this premise in relation to Aboriginal land rights:

The doctrine of Aboriginal land rights does not originate in English or French property law, and it does not stem from native custom. It is an autonomous body of law that bridges the gulf between native systems of tenure and the European property systems applying in the settler communities. It overarches and embraces these systems, without forming part of them.

As Dickson J. recognizes in the Guerin case, Aboriginal land rights are thus sui generis. See Slattery, "Understanding Aboriginal Rights," supra note 24 at 744-45.

Van der Peet (S.C.C.), supra note 8. The importance of culture to the survival of Aboriginal peoples as Aboriginal peoples may be seen in the statement made by Leroy Little Bear, "What's Einstein Got to Do With It?" in R. Gosse, J.Y. Henderson, \& R. Carter, eds., Continuing Poundmaker and Riel's Quest (Saskatoon: Purich Publishing, 1994) at 70-71: 
check on inappropriate analogies being drawn from other legal sources, and counteracts the powerful influence of non-Aboriginal laws in the development of Aboriginal rights jurisprudence. The sui generis doctrine, therefore, entails the need to intermingle common law and Aboriginal conceptions. Such symmetry would allow for the recognition of Aboriginal difference while building strong ties of cooperation and unity between Aboriginal and non-Aboriginal people. The act of incorporating pre-existing Aboriginal rights into the common law - and the common law's imparting of its protection to those rights - also makes necessary the incorporation of some elements of the common law in the interpretation of these rights. The use of the sui generis doctrine in Aboriginal rights jurisprudence therefore does not require that common law concepts be discarded, ${ }^{156}$ only that there be a retreat from their mechanical implementation. ${ }^{157}$ Since Aboriginal rights are not dependent upon Crown recognition or affirmation, ${ }^{158}$ framing them as sui generis simply reflects the notion that not all principles underlying common law precepts are applicable to analyses of Aboriginal rights. $^{159}$

Taking the perspectives of Aboriginal peoples - those connected to their contemporary cultural and physical survival ${ }^{160}-$ is an important starting point in

Culture we can define as a collective agreement among a group of people. That culture, that collective agreement, defines what life is all about. It brings to its members the accepted ways by which knowledge is obtained. It brings to its members a way to organize all the data that come to a person through the senses, through the eyes, ears and so on. It helps that person arrange things in a nice neat order. A collective agreement, a culture, tells its members how to deal with the gods, what to expect from them, what constitutes fulfilment and frustration. A culture helps people order their world into nice neat little categories. That's what we can refer to as a philosophy.

Note also the statements made in the opening address of the plaintiffs in Delgamuukw (S.C.), supra note 4, reprinted [1988] 1 C.N.L.R. 14 at 36:

If one culture refuses to recognize another's facts in the other culture's terms, then the very possibility of dialogue between the two is drastically undermined. The challenge for this court in understanding the nature of Gitskan and Wet'suwet'en validation of facts and in accepting Gitskan and Wet'suwet'en history as real, is part of the Court's task in treating Gitskan and Wet'suwet'en societies as equals.

Note the comments made by Wallace J.A. in Delgamuukw (C.A.), supra note 4 at 572:

One must not be asked to drop all Western legal thought at the door in identifying Aboriginal rights and characterizing their content and implications. They are unique. That does not mean that useful comparison and analogy is impossible. After all, these rights receive their recognition and protections through the common law....

See, in particular, Pawis, supra note 69; Grammond, supra note 127.

See Sparrow, supra note 4. The unique nature of Aboriginal land rights was highlighted by the Supreme Court of Canada in Paul v. Canadian Pacific Lid. (1988), 53 D.L.R. (4th) 487 at 505 (S.C.C.): "The inescapable conclusion ... of Indian title up to this point is that the Indian interest in land is truly sui generis. It is more than the right to enjoyment and occupancy although ... it is difficult to describe what more in traditional property law terminology."

For example, the use of the contra proferentum rule, which holds that a contract is to be construed strictly against its framer, may be appropriately used in the context of treaty interpretation, but the parol evidence rule, which restricts the use of evidence other than the document itself, is inappropriate due to the nature of treaty negotiations and the language and conceptual barriers that existed between the parties. See L.I. Rotman, "Taking Aim at the Canons of Treaty Interpretation in Canadian Aboriginal Rights Jurisprudence" (1997) 46 U.N.B.L.J. 11 [hereinafter "Taking Aim"]. Sparrow, supra note 4 at 402. 
deciding which aspects of Aboriginal rights should depart from conventional common law formulations. This approach is consistent with ensuring that Aboriginal rights are not defined in the way they have historically been regulated and practiced. ${ }^{161}$ While the Supreme Court has only articulated its rejection of frozen rights theory in response to the government's historic regulation of rights, adhering to the Aboriginal perspective of the meaning of the rights at stake similarly dictates that they ought not be defined by reference to the community's historic practices. The definition of Aboriginal rights by reference to specific historic practices misinterprets the Supreme Court's rejection of frozen rights theory. ${ }^{162}$ Clearly, if Aboriginal rights exist to secure physical and cultural survival, they cannot be ascertained exclusively by reference to pre-contact "Aboriginality." There are far more relevant aspects to the determination of Aboriginal rights. Aboriginal rights have two primary components, a theoretical and a material element. The theoretical element is a constant, and concerns the underlying purpose for the right in question - namely the contemporary cultural and physical survival of Aboriginal societies. Meanwhile, the material element of the right involves its practice, which is fact and site-specific. Therefore, under the sui generis formulation, rights which are integral to the distinctive cultures of Aboriginal societies are, simultaneously, universal and fact and site-specific.

For these reasons, this article suggests that interpretations of Aboriginal rights which focus upon temporal considerations in the place of theoretical and material elements are misguided, and should be rejected. For example, in the Van der Peet case, Lamer C.J.C.'s finding that Van der Peet's sale of fish was not an exercise of an Aboriginal right focused upon the length of time that the Sto:lo people had engaged in the commercial sale of fish, rather than on whether the commercial sale of fish was necessary for Sto:lo physical and cultural survival. ${ }^{163} \mathrm{He}$ held that post-contact European influences were directly responsible for the prevalence of Sto:lo commercial fishing practices. ${ }^{164}$ What the Chief Justice neglected to consider was whether the commercial sale of fish to the Europeans was necessary for the cultural and physical survival of the Sto:lo nation.

If the commercial sale of fish is integral to the cultural and physical survival of the Sto:lo nation, then evidence as to the length of time that the practice was engaged in should not have been the major factor in determining whether the practice in question was a protected Aboriginal right. Time-based determinants of rights are entirely incapable of protecting the collective rights of Aboriginal peoples. ${ }^{165}$ Such formulations

161 While the Supreme Court of Canada has recognized the need to avoid using this "frozen rights" theory, the Sparrow court only articulated its rejection of frozen rights theory in response to the historic regulation of rights, not their actual practice. See La Forest J.'s majority judgment in Mitchell v. Peguis Indian Band (1990), 71 D.L.R. (4th) 193 (S.C.C.) and the analysis of it in Rotman, "Provincial Fiduciary Obligations," supra note 43 at 770-75. See Sparrow, supra note 4 at 397; Rotman, "Hunting for Answers," supra note 78.

See the discussion of Van der Peet (S.C.C.), supra note 8.

Van der Peet (B.C.C.A.), supra note 139 at 472-73.

For a thoughtful discussion of the difficulty of applying notions of collective Aboriginal rights in an individually oriented rights regime, see L.E. Trackman, "Native Cultures in a Rights Empire: Ending the Dominion" (1997) 45 Buf. L. Rev. 189. 
base the retention of Aboriginal rights on the maintenance of the "Aboriginality" in a pre-colonial state. ${ }^{166}$ As Kent McNeil has noted:

If ... [Aboriginal peoples] try to adapt to meet the changes in circumstances caused by European colonization, as they must to survive, their activities are no longer 'Aboriginal' and so are not encompassed by their Aboriginal rights. According to ... [this] approach, then, the Aboriginal peoples are denied the opportunity to develop contemporary ways of life within their own communities on the basis of their Aboriginal rights. If sustained, this approach will probably result in the disappearance of the Aboriginal cultures which make those communities distinct, as the Aboriginal peoples will be obliged to assimilate into the dominant Canadian culture which surrounds them in order to survive. ${ }^{167}$

As Professor McNeil suggests, the Court's exclusive reference to time should not be an important determinant in characterizing Aboriginal rights. If Aboriginal rights are dynamic and evolving rights which are not to be restricted to their "primeval simplicity and vigour," they must be allowed to adapt to changing circumstances, such as the intrusion of European settlement and laws. If the fact of European settlement created the cultural and physical need for the Sto:lo to engage in the commercial sale of fish, then that activity ought to be recognized as a protected Aboriginal right regardless of the length of time it was exercised, or whether it was "induced and driven by European influences." 168

As Macfarlane J.A. recognized in the B.C. Court of Appeal's decision in Van der Peet, "the arrival of the Europeans brought new customs, new ways and new incentives.... As a practical consequence the aborigines probably began to adjust to those changes."169 The Supreme Court's denial of legal protection for the Sto:lo Nation's "new" practices that were invented to meet these changing circumstances is inappropriate. It represses the legitimate exercise of the more fundamental and universal component of Aboriginal rights - that of taking appropriate measures in order to preserve their cultural and physical survival as a distinct people. It wrongly penalizes Aboriginal similarity and falsely supports a caricature of Aboriginal difference. It also represents an unacceptable application of the frozen rights theory articulated in Sparrow. The determination of Aboriginal practices integral to their distinctive cultures should be judged by asking whether the practice in question is "central and significant"170 to the physical and cultural survival of the group in question. If the practice sustains either (a) the survival of the group; or (b) if "without this practice ... the culture in question would be fundamentally altered or other than what it is,"171 the practice ought to qualify as an Aboriginal right under s. 35(1) regardless of its longevity. Sto:lo culture will be altered, and made other than what it is, if their trade in fish does not receive constitutional protection because this activity is of central significance to their physical and cultural survival. The facts in the Van der Peet case

\footnotetext{
i6s McNeil, "The Meaning of Aboriginal Title," supra note 149 at 152.

167 Jbid.

168 Van der Peet (B.C.C.A.), supra note 139 at 473.

$169 \quad$ Ibid. at $\mathbf{4 7 2}$.

170 Van der Peet (S.C.C.), supra note 8 at 204 (para. 55).

171

Ibid.
} 
demonstrate that the sale of fish to settlers was, and is, integral to the Sto:lo Nation in sustaining their culture in the changing world of colonialism.

As the sui generis doctrine has developed, it has become increasingly clear that many judgments, like Van der Peet, have not fully addressed the notion of contemporary survival as the universal component of Aboriginal rights. For the most part, courts have limited their remarks to the particular histories and facts in dispute. ${ }^{172}$ For example, an earlier Supreme Court noted, before s. 35(1) called "for a just settlement for Aboriginal peoples" and "renounced the old rules of the game," 173 that:

Claims to Aboriginal title are woven with history, legend, politics and moral obligations. If the claim of any Band in respect of any particular land is to be decided as a justiciable issue and not a political issue, it should be so concluded on the facts pertinent to that Band and to that land, and not on any global basis. ${ }^{174}$

With the constitutionalization of Aboriginal rights and their recent description as sui generis, the courts must go beyond this older description and now protect both the specific practices of Aboriginal people, as well as the physical and cultural survival of their societies. The court must embrace a sui generis notion of Aboriginal rights which simultaneously accepts and recognizes the facts pertinent to the group, as well as their affirmation on a global basis.

The recognition and affirmation of the physical and cultural survival of Aboriginal societies provides a principled basis for inquiries into various fact and site-specific Aboriginal practices. These first-order implied rights and principles, which all Aboriginal rights include, can be located in Aboriginal laws, customs and perspectives. Since Aboriginal laws continue to give meaning and content to all Aboriginal rights, ${ }^{175}$ form a part of the "laws of Canada," 176 and embody the principles of cultural and physical survival, ${ }^{177}$ reference by analogy to these perspectives in Canadian law

This ignores the importance of context noted, for example, in Taylor and Williams, supra note 124. See Sparrow, supra note 4 at 406.

Kruger, supra note 132 at 437.

The High Court of Australia has recognized that the laws of indigenous peoples are implicit in other rights that are protected by the common law. As Brennan J. observed in Mabo v. Queensland [No. 2] (1992) 175 C.L.R. 1 (H.C. Aust.) at 43-44:

Where a clan or group has continued to acknowledge the laws and (so far as practicable) to observe the customs based on the traditions of that clan or group, whereby their traditional connection with the land has been substantially maintained, the traditional community title of that clan or group can be said to remain in existence. The common law can, by reference to the traditional laws and customs of an indigenous people, identify and protect the native rights and interests to which they give rise. ... [T] The rights and interests in land are matters to be determined by the laws and customs of the indigenous inhabitants.

See also the judgment of Lambert J.A. in Delgamuukw (C.A.), supra note 4 at $636-40$, and discussed in Part I, above.

Roberts, supra note 7.

For descriptions of Aboriginal laws and their preoccupation with cultural and physical survival see A. Mills, Eagle Down is Our Law: Witsuit 'en Law, Feasts and Land Claims (Vancouver: U.B.C. Press, 1994); G. Wa \& D. Uukw, The Spirit in the Land (Gabriola, B.C.: Reflections Press, 1992); E.A. Hoebel, The Law of Primitive Man: A Study in Comparative Legal Dynamics (New York: 
recognizes a foundational and unifying principle in Canadian Aboriginal rights jurisprudence. ${ }^{178}$ Since these laws and/or legal perspectives they generated have "always constituted an integral part of their distinctive culture... for reasons connected to their cultural and physical survival," 179 they constitute a principled reference point in the interpretive framework of Aboriginal rights, upon which other Aboriginal rights rest. ${ }^{180}$ Unfortunately, the courts have not always recognized this fact.

In Jack and Charlie v. The Queen, ${ }^{181}$ the appellants, members of the Coast Salish Nation, had been convicted of hunting deer outside of open season. The evidence presented at trial indicated that the appellants killed the deer for use by one of their relatives for ceremonial purposes in which the burning of raw meat was required. The practice for which the deer was killed was described, by an anthropologist, as a means of serving the spirits of the dead. The deceased ancestors transmit their desires for things they have left behind in this world to close relatives by way of dreams. The burning of food - whereby the essence of the food is transmitted to the essence of the deceased through the smoke created - is the manner in which the recipients of the dreams attempt to satisfy the ancestors' desires. The appellants took the deer so that a relative, who had been visited by the spirit of her great-grandfather, could burn raw deer meat for him as he had requested. ${ }^{182}$

The appellants contended that the provincial wildlife statute prohibiting the hunting of deer at certain times interfered with the appellants' religious freedom. The Crown insisted that the fundamental issue was "whether hunting by Indians for the propitiation of the dead enjoys higher constitutional protection than hunting for sustenance of the living." ${ }^{183}$ In upholding the convictions, the unanimous decision of the Supreme Court of Canada was that, while the appellants' truly believed in the necessity of killing the deer to provide meat for the burning ceremony, they' could have just as easily used frozen deer meat as fresh. ${ }^{184}$ The court also found no evidence that the killing of the deer was part of the religious ceremony. In dismissing the appellants' arguments, the

Atheneum, 1954); K.N. Llewellyn \& E.A. Hoebel, The Cheyenne Way: Conflict and Case Law in Primitive Jurisprudence (Norman, Okla.: University of Oklahoma Press, 1941); M. Gluckman, Politics, Law and Ritual in Primitive Society (Chicago: Aldine, 1965).

It is only through the operation of pre-existing Aboriginal laws that Aboriginal people occupied and possessed land, exercised rights to hunt and fish, or entered into treaties and relationships with the Crown. These laws continued upon contact with non-Native people and the fruits of these laws have been recognized by Canadian courts as Aboriginal title, customary marriage, hunting and fishing rights, etc.

180 That is not to say that courts will be able to reference a unified Aboriginal law which will apply in the same way to different Native peoples. Obviously, Aboriginal peoples will have their own specific laws that are factually particular to their territories. For a greater discussion of First Nations' law as a reference point for Canadian law, see Borrows, "With or Without You," supra note 153 .

This is described ibid. at 643-44.

Ibid. at 649.

18 Ibid. at 650: "There was no evidence that the use of defrosted raw deer meat was sacrilegious as is alleged in the appellants' factum." 
court analogized the taking of the deer for use in the burning ceremony to the taking of wine by a clergyman for use in conducting a sacrament. ${ }^{185}$

What the court in Jack and Charlie failed to appreciate is that the sui generis content of Aboriginal rights encompasses more than the specific practice itself. The killing of the deer has consequence beyond its "fact" as an isolated Aboriginal practice; it has significance as a Salish legal exigency, and as an event related to the cultural survival of the group. The Supreme Court's description of the specific practice of burning the raw deer meat fails to recognize these elements. For example, the burning of the deer meat entails more than the actual tracking and killing of an animal and offering its flesh. The activity includes the entire process leading up to and including that specific practice, and is enmeshed in the web of legal obligations required within the Salish nation. It is an experience that sustains the cultural and physical survival of the group.

Considering the practice by sole reference to the deer meat (and thus suggesting that frozen deer could be a substitute), misses the cultural and legal context within which the ceremony is performed. There is no appreciation of the matrix of family responsibilities and relationships that are triggered by the requirement of obtaining fresh deer meat for this ceremony. There is no understanding of how the people plan for the trip, discuss its purpose, remember the great-grandfather, share their food and supplies, and experience nature together. There is no acknowledgment of the internal contractual and constitutional legal principles which govern the parties' conduct within Salish society. The event's narrow construction overlooks community participation that would accompany the preparation and dressing of a newly killed deer. The Court did not account for the people lifting the deer from the truck, taking it in the house or shed, skinning it, sitting around the table working at it, and discussing their routines and relationships in very specific ways.

Finally, the Court did not mention how the use of fresh deer meat for the ceremony would draw the community together in a way that retrieving frozen deer meat from a freezer never would. The immediacy of the life and death would not be as culturally poignant if frozen deer meat were used. These understandings provide the "Aboriginal perspective on the meaning of the right at stake" and illustrate the reasons the Court must look beyond specific fact and site determinations in defining Aboriginal rights. The practices for which protection is sought can not be understood in the same way as one would individual rights. ${ }^{186}$ The practices have a collective purpose which underpins their recognition and affirmation - cultural and physical survival. The courts must gain a greater appreciation of this difference. Therefore, in making sui generis determinations of Aboriginal rights, courts must look to notions of collective physical and cultural survival, as well as specific Aboriginal laws, customs and practices. Reading both these elements into the jurisprudence would serve as a more appropriate interpretive prism through which the courts may find resolutions to Aboriginal rights disputes. 


\section{Conclusion}

The true challenge of the sui generis doctrine lies in the common law's ability to accept and receive Aboriginal principles and perspectives. It is one thing to state that Aboriginal rights are sui generis, but it is a far more onerous proposition to implement a truly sui generis approach to Aboriginal rights. These rights should be approached differently since they do not necessarily correspond to other common law rights, or share their same theoretical or practical basis. Their different approach requires the creation of a distinctive method of interpreting Aboriginal rights that is reflective of the unique legal nature of those rights and accounts for cultural differences in their exercise. Precedent for such a method of analysis may be found in both common law and Aboriginal systems. Within the former, for example, common law canons of Indian treaty interpretation make use of Aboriginal conceptions and understandings to interpret Aboriginal treaty rights. ${ }^{187}$ Meanwhile, Aboriginal laws and legal perspectives encode principles which preserve contemporary Native practices and ensure the continued cultural and physical survival of Aboriginal peoples. ${ }^{188}$

This article has noted that the description of Aboriginal rights as sui generis is not an entirely recent phenomenon, even if the actual use of the phrase to describe them is a contemporary creation. It has also attempted to make sense of the various descriptions of Aboriginal rights as sui generis. The doctrine replaces approaches which insisted that Aboriginal rights be conceptualized entirely in common law terms in order to be given protection. It provides a balance between common law and Aboriginal conceptions; it neither requires the complete rejection of the common law nor a complete shift to an entirely Aboriginal-based method of analysis. The sui generis approach should, therefore, not be perceived as a threat to the common law, but should be regarded as an aid to its development. In utilizing both common law and Aboriginal perspectives, there will be a need to resolve matters of inconsistency between the systems. The suggestions as to the method of implementing the sui generis doctrine offered herein can serve to guide judicial forays into the relatively unexplored world of sui generis Aboriginal rights.

In the end, some may question whether the use of sui generis principles in the analysis of Aboriginal rights may hamper those groups who wish to use common law principles to support their rights. The authors share this concern. In partial response, this article has suggested that since the sui generis concept acts as a bridge, it can render appropriate the use of both common law and Aboriginal conceptions where these concepts pay heed to the Aboriginal perspective on the legal nature of the right in question and ultimately facilitate the cultural and physical survival of the Aboriginal peoples. The sui generis concept is significant since it recognizes the need to bring together separate systems and principles which have a mutually beneficial, interactive, and practical co-existence. This intermingling can achieve a just and equitable solution for individual litigants and Aboriginal peoples as societies. The sui generis concept can embody the harmonization of distinct world views to facilitate and protect the 
differences between societies, while building upon areas of mutual agreement. The sui generis doctrine is a more effective vehicle for the resolution of Aboriginal rights issues than past judicial practice because it brings these issues squarely within an appropriate cultural and ideological context.

In writing this article, the authors have attempted to suggest a more principled basis for the use of a sui generis approach to interpreting Aboriginal rights. The issues explored are ultimately distilled in the title of this article: does the sui generis nature of Aboriginal rights make a difference? Does it assist in understanding Aboriginal difference without unnecessarily rejecting the similarities between Aboriginal and non-Aboriginal peoples? It has been illustrated that the sui generis nature of Aboriginal rights does, in fact, have the potential to make a difference ${ }^{189}$ - by helping us understand other legal perspectives, and their relationship to cultural and physical survival - but only if it is implemented to account for the principles outlined in this article. Whether this will be done remains to be seen.

The judiciary's adherence to the sui generis doctrine of Aboriginal rights may also have a positive effect on the availability of remedies for violations of Aboriginal rights. As Kent Roach notes in his article, "Remedies for Violations of Aboriginal Rights" (1992) 21 Man. L.J. 498 at 498, the judiciary is hesitant to provide remedies to Aboriginal groups due to the uncertainty which surrounds the existence, content, and exercise of those rights:

Rights and remedies are, of course, interconnected. Judges do not decide questions of rights without worrying about remedies and the fact that judicial remedies for violations of Aboriginal rights are unexplored may deter some judges from recognizing Aboriginal rights [footnote omitted].

Without an understanding or awareness of the remedial implications of their decisions, the courts are reluctant to provide relief which could have much farther-reaching implications than what initially appears. The danger of creating a floodgate of similar claims is another consideration which creates resistance to the provisions of remedies that are not purely monetary. Once the sui generis nature of Aboriginal rights becomes more commonplace through the greater judicial understanding of the basis for their differential treatment, issues such as these should no longer impede the availability of remedies for Aboriginal and treaty rights violations. 